\title{
Modelling Sustainability Risk in the Brazilian Cosmetics Industry
}

\author{
André Luiz Romano ${ }^{1, *}$, Luís Miguel D. F. Ferreira ${ }^{2}(\mathbb{D})$ and Sandra Sofia F. S. Caeiro ${ }^{1,3}$ \\ 1 Department of Science and Technology, Universidade Aberta, 1250-100 Lisboa, Portugal; scaeiro@uab.pt \\ 2 CEMMPRE, Department of Mechanical Engineering, University of Coimbra, 3004-531 Coimbra, Portugal; \\ luis.ferreira@dem.uc.pt \\ 3 Center for Environmental and Sustainability Research (CENSE ), School of Science and Technology, \\ NOVA University of Lisbon, 2829-516 Lisboa, Portugal \\ * Correspondence: 1700945@estudante.uab.pt or reromano1973@hotmail.com
}

Citation: Romano, A.L.; Ferreira, L.M.D.F.; Caeiro, S.S.F.S. Modelling Sustainability Risk in the Brazilian Cosmetics Industry. Sustainability 2021, 13, 13771. https://doi.org/ $10.3390 /$ su132413771

Academic Editor: Ming-Lang Tseng

Received: 4 October 2021

Accepted: 7 December 2021

Published: 14 December 2021

Publisher's Note: MDPI stays neutral with regard to jurisdictional claims in published maps and institutional affiliations.

Copyright: (c) 2021 by the authors. Licensee MDPI, Basel, Switzerland. This article is an open access article distributed under the terms and conditions of the Creative Commons Attribution (CC BY) license (https:// creativecommons.org/licenses/by/ $4.0 /)$.

\begin{abstract}
Supply chains involve several stakeholders, with different environmental, social, economic, and ethical attributes, and are exposed to various risks along all stages. One of these risks relates to conditions or events related to sustainability that have the potential to generate harmful reactions from stakeholders in the supply chain. Those risks can materialize through stakeholders' responses, when they hold companies responsible for unfavorable conditions in the supply chain, leading to reputational damage. Understanding the supply chain's sustainability risk factors can help companies improve supply chain resilience. This article aims to empirically identify the most influential risk factors in the Brazilian cosmetics supply chain and, additionally, analyze the interrelationships between these risks. The methodology combines interpretative structural modeling (ISM) and matrix cross-impact multiplication (MICMAC) analysis, and is grounded in the opinions of cosmetics industry experts. Firstly, the critical causes and consequences are identified, called factors. Secondly, the ISM model is built, representing the interrelationships between factors and their hierarchy. Thirdly, the MICMAC analysis is performed, unfolding the strength of the relationship among the influencing factors. Fourthly, measures are designed to act on and mitigate the factors identified in the previous steps. The results show that the Brazilian cosmetic companies analyzed do not take advantage of the opportunity to take leadership in cost reduction, differentiation, and engagement with their partners. "Financial risks" were identified as the most influential among the set of risks, while "Technology and innovation" and "Legislation and responsibility" were identified as root risk factors. This research identified measures that could be implemented to act on and mitigate the root risk factors, thus contributing to the research relating to sustainability risks in supply chains.
\end{abstract}

Keywords: sustainability risks; supply chains; interpretive structural modelling; matrix impact of cross multiplication applied to classification analysis; cosmetics industry

\section{Introduction}

Over the last century, economic and social progress has been accompanied by environmental degradation. This process is directly related to the increased risks in the systems on which future development is based [1]. Sustainability risks in the supply chain can materialize through stakeholder reactions when they hold companies responsible for illegitimate supply chain conditions, leading to a loss of reputation [2-4]. A negative reputation potentializes financial losses via changing consumer purchase intentions and brand boycotts [5]. Balancing sustainability and the disruption of supply chains requires organizational ambidexterity [6].

Supply chains involve different environmental, social and ethical attributes $[7,8]$. There is evidence of financial consequences of companies' social, economic, and moral sustainability risk [9-11]. According to [6], the study of different actors in different geographic spaces is relevant to having a broader view of the challenges to sustainability. 
Different countries and companies present sustainability risks, monitored through modern information and communication technology techniques [4-12]

The risk assessment of external and internal factors of a supply chain is an important management component [13]. Risks are potential conditions or events in the supply that may trigger reactions that are harmful to companies' businesses [9,14]. Supply chain sustainability risk alludes to conditions or events related to sustainability that have the potential to generate harmful reactions from stakeholders in the supply chain [15]. In general, previous studies focus on analyzing a single risk factor, such as customer boycotts or employee strikes $[10,16]$. This study covers the sources and causes of sustainability risks for purchasing companies, but the consequences and results that the risks can trigger are also considered. Risks are harmful effects that can affect a purchasing company based on a supplier's unethical or immoral conduct [17]. Events at suppliers are sometimes associated with the negligent behavior of the suppliers themselves. Supplier events are sometimes associated with their own negligent behavior.

However, the inadequate management of those events can have a negative impact on companies and damage reputation, which could increase financial losses due to changing consumer purchase intentions or even boycotts of the brand $[10,11,18]$. The consequences of scandals can cause companies to lose value [2,11,19]. Therefore, understanding the sustainability risks of the supply chain can help companies improve their resilience [20].

Unlike traditional risk factors that influence supply chains, which might relate to interruptions in production activities at each stage of the chain, sustainability risks do not always involve these interruptions [8]. The understanding of sustainability risks in this research is interlinked to environmental, social and economic risks dimensions [2]. Additionally, according to the Triple Bottom Line (TBL) approach of sustainability profit, people and the planet are connected [21]. Economic risks are those that are linked to all the company's activities in different stages of its supply chain, such as the purchase of materials and components, internal processes such as manufacturing, storage and internal distribution, and the sale of goods or services, that is, the so-called business cycle, which affects the company in its various relationships. The supplier's selection decisions are at the center of economic risks [14]. On the other side, social risks in supply chains are determined by local socioeconomic conditions [20]. Aspects such as human rights, nondiscrimination or combating child and forced labor are fundamental issues for the social dimension in supply chains [22]. It also includes issues related to the responsibility of products and procedures when selecting suppliers [14]. Finally, environmental risks have garnered attention since the emergence of concerns about the use of natural resources in the 1970s. The most critical concerns of the environmental dimension are related to the use of natural resources, waste management, better environmental technologies, emissions, energy and water consumption, and the preservation of biodiversity [22]. However, these risk factors influence each other, so it is crucial to analyze how this influence can create a hierarchical structure between risk factors.

According to [23], an increasing number of studies have been carried out involving developments in the economic, social and environmental performance of supply chains, including some studies on the cosmetic sector. Several aspects of the cosmetic sector's sustainable practices are usually studied. The sector has indicated a concern with replacing synthetic and unsustainable ingredients with sustainable and natural alternatives derived from natural, organic, or green chemistry [23,24], called green cosmetic [25]. Studies in the cosmetics sector also evaluate the consumer's functionality, safety, stability, and aesthetic preferences, and conduct comparisons between various ingredients.

The Brazilian cosmetic industry is representative on a global scale. Ref. [26] indicates that Brazil is the fourth largest consumer market globally for cosmetics, with a $6.2 \%$ share of the global total, and has already consolidated itself as the first market in Latin America, with over $30 \%$ of the market share in that region. Even with the instability of the Brazilian economy, the growth of the cosmetics market in Brazil has strengthened 100\% national brands in the context of local production, led by the companies Natura, Grupo 
Boticário, and Unilever. This strengthening has created high-complexity supply chains in the country, with an essential relationship between cosmetic companies' operations and the sustainability practices of these chains, related to the use of natural products that help protect the Amazon rainforest [27-29].

If risk factors associated with sustainability are not adequately managed, they will substantially impact companies' performances. As a result, effective risk management is of great importance in supply chains. In this sense, understanding the complexity of these risks and the interrelation between them is an essential aspect of this research [4,29]. Risk is understood in this study as all the problems in the cosmetics supply chain related to sustainability, causing interruptions in supply, or not, but often damaging the company's image. This article aims to empirically identify the most influential risk factors in Brazilian cosmetics supply chains, and additionally, analyze the interrelationships between these risks. A literature survey on sustainability risks was carried out to address this issue, and discussions were held with various experts to maintain a supply chain perspective and achieve a holistic understanding of the problem. The experts that were selected from the identified companies operate within the stated sector in Brazil (namely, importing, producing, distributing, marketing and exporting different cosmetic products), and were used primarily to collect feedback at various stages of the supply chain.

The experts were chosen to assist in selecting relevant risks in cosmetic supply chains and develop a model based on combining two techniques: the interpretive structural modeling (ISM) methodology and matrix-based multiplication applied to a classification (MICMAC) analysis. Structured approaches such as ISM and MICMAC help us understand mental models, showing the relationships between variables [30-32]. Interpretive structural modeling has been used in many applications [33-35].

Focus companies have a central role in disseminating good sustainability practices. They can support Sustainable Development Goal (SDG) number 9, which indicates the need to build resilient infrastructure, promote sustainable industrialization and foster innovation [1].

This article contains five sections. The second section describes the literature. The third section describes the methodology implemented in the study, step by step. Results are presented in section four through the development of ISM and the MICMAC analysis. The fifth section gathers the main discussion points and conclusions of the study, highlighting opportunities for future research.

\section{Literature Review}

\subsection{Sustainability Risks in Supply Chain}

This section summarizes sustainability risks. This research has a multidisciplinary approach, grouping risk factors according to TBL dimensions $[21,36]$. Sustainability risks in supply chains can impact more than one dimension, and are classified as internal or external risks [13]. Companies can respond to these risks in several ways, with no standardized response for all situations-it will depend on the realities of different supply chains in terms of social and environmental requirements and attributes. Moreover, supply chain managers are pressured by stakeholders to manage sustainability risks due to the fear of losing company value. Stakeholder theory deals with the different perspectives of value in a wide range of individuals and organizations [37,38]. Other studies have evaluated sustainability risks' impacts on economic [39], social [40], and environmental dimensions [41], and the performance of supply chains sustainability risk management [2]. Sustainability approaches have been around for a long time. However, most guidelines and standards address sustainability issues through compartmentalization, thereby separating the economic, environmental, and social dimensions [20,42]. So, there is a dearth of research assessing sustainability risk in the supply chain in an integrated way, considering all dimensions of sustainable development and their interconnections. 


\subsubsection{Economic Risks}

The economic risks have relevant characteristics. While traditional indicators aim to capture interruptions that impact production activities along the supply chain, sustainability risks can exist and be perceived without interrupting the flow of materials and information. Economic risk can also be called an operational risk since it is linked to the company's activity in the different stages of its supply chain, such as the purchase of materials and components, internal processes, storage, distribution, and sales [14,43]. Ref. [20] typifies economic or operational risks as follows: risks from suppliers, risks from internal company processes, risks from customer demand, and risks from factors associated with the corporation. The economic dimension of sustainability risk can be external to the chain-boycotts, energy price volatility, financial crisis and litigation risks external to the chains - or internal to the chain — antitrust claims, bribery and corruption, false allegations and dishonesty, patent infringement, pricing and tax evasion $[10,11,13]$.

\subsubsection{Social Risks}

Social risks in supply chains are determined and influenced by local socioeconomic conditions. Aspects such as human rights, non-discrimination or child and forced labor are fundamental issues in the social dimension, and when managed, they can lead to social risks for supply chains [22]. Other issues include product responsibility and the procedures adopted for selecting suppliers with accepted social practices [14]. The social risks in supply chains can be (i) internal—child or forced labor, discrimination, dangerous work environment, inhumane treatment, unfair wages, unethical treatment of animals, excessive working hours—or (ii) external—demographic challenges, pandemics, social instability, or restlessness [13]. Several authors identify ways to assess the social risks by combining indicators, depending on data availability [44]. However, it is necessary to combine the social risks of each location to assess the global social risk of a supply chain, offering a contextual and systemic view [45].

Managing companies' inherent supply chain risks has become decisive for their growth, and can generate competitive advantages [46]. Risk management has traditionally focused on "financial risks", ignoring the social risks that can affect supply chains and often trigger "financial risks". The traditional bias, focused on financial performance, disregards relevant aspects, as it presents a partial view of the business system [8]. Several authors argue that if a supply chain has social problems, this will not stop the company from continuing its operation [13]. However, if the media release this information, companies may lose their reputation and part of their financial value, with examples such as Foxconn, Apple or Zara [47]. Studies regarding social risks have gained importance, as verified by the recent studies by [46]. The conceptual foundations of risk management in the social supply chain have been improved, aiming at the formalization and improvement of the field.

\subsubsection{Environmental Risks}

Environmental risks refer to the possible impacts of environmental factors in the supply chain, considering the use of natural resources, ecological products and practices, the consumption of energy and water, in addition to care for biodiversity [48]. Ref. [13] establishes ten categories of supply chain environment risks, which are either internalenergy consumption, environmental accidents, greenhouse gases, pollution of water and environmental resources, excessive waste products, packaging —or external—natural disasters, heatwaves and droughts, water scarcity. Internal risks are perceived as more relevant than external risks since they originate from the actions, or lack thereof, of companies or their suppliers, who are given greater direct responsibility to control or mitigate these risks. External risks are generally unpredictable, and are more challenging to manage and assign responsibilities for. On the other hand, internal environmental risks are directly controllable by supply chains, such as the type of fuel used in operations, or the quantity of effluents generated. 
Meanwhile, external environmental risks are sudden, and thus not directly controllable [49]. An essential part of sustainability risk is related to the irresponsible behavior of suppliers, the potential risks of adverse advertising, damages to reputation and legal obligations [50]. Companies can suffer severe losses due to social, ecological, or ethical problems in their supply chains [2]. The environmental dimension shows that many scandals and accidents have neglected environmental issues in supply chains.

This research, summarized in Table 1, has helped generate knowledge about risks and their description, as well as the dimensions to which they belong, whether internal or external. However, too little attention has been paid to analyzing the relationships between the different risks in the supply chain, which invariably affect each other [51,52]. This study covers the sources of sustainability risks for purchasing companies, and the consequences that the risks can trigger are also necessarily considered.

Table 1. List of the sustainability risks, as well as their descriptions, dimensions, origins, and responses.

\begin{tabular}{|c|c|c|c|c|c|}
\hline $\begin{array}{l}\text { Risk (Sources and } \\
\text { Consequences) }\end{array}$ & Description & Dimension & Origins & Response & References \\
\hline Energy consumption & Inefficient energy use for the operations & $\mathrm{EN}$ & IN & MI, PR & {$[53,54]$} \\
\hline $\begin{array}{l}\text { Environmental } \\
\text { accidents }\end{array}$ & $\begin{array}{l}\text { Accidents in operations that affect } \\
\text { the environment. }\end{array}$ & EN & IN & $\begin{array}{l}\text { MI, PR, RE, } \\
\text { CO, IN }\end{array}$ & {$[48,55]$} \\
\hline Greenhouse gases & $\begin{array}{c}\text { Emission of gases that contribute to the } \\
\text { greenhouse effect }\end{array}$ & EN & IN & PR, AV, SH & [56] \\
\hline $\begin{array}{l}\text { Legal and } \\
\text { responsibility }\end{array}$ & $\begin{array}{l}\text { Failure of regulations. Liability to 3rd party } \\
\text { companies. Unfair wages. Complexity in } \\
\text { legislation. Delays in the process. }\end{array}$ & $\begin{array}{l}\mathrm{EN} \\
\mathrm{SO} \\
\mathrm{EC}\end{array}$ & $\begin{array}{l}\text { IN/ } \\
\text { EX }\end{array}$ & $\begin{array}{l}\text { MI, PR, CO, } \\
\text { IN, CT, AV }\end{array}$ & {$[52]$} \\
\hline $\begin{array}{c}\text { Ecological } \\
\text { damage/Pollution }\end{array}$ & $\begin{array}{l}\text { Air, water or soil contamination due } \\
\text { operations or products. Interruptions in } \\
\text { operations caused by ecological issues. } \\
\text { Interference in habitats of } \\
\text { endangered species. }\end{array}$ & EN & IN & $\mathrm{RE}, \mathrm{AV}, \mathrm{SH}$ & {$[43,48]$} \\
\hline $\begin{array}{l}\text { Excessive product } \\
\text { waste }\end{array}$ & $\begin{array}{l}\text { Unwanted material produced during or as a } \\
\text { result of a process. }\end{array}$ & EN & IN & MI & [51] \\
\hline Packaging & $\begin{array}{l}\text { Failure to meet packaging standards or } \\
\text { excessive packaging. }\end{array}$ & EN & IN & MI, RE & {$[48,57]$} \\
\hline Natural disasters & $\begin{array}{l}\text { Disruptions caused by natural disasters } \\
\text { (hurricanes, flood, storms, severe } \\
\text { weather conditions). }\end{array}$ & EN & EX & $\begin{array}{l}\text { MI, RE, CO, } \\
\text { IN, }\end{array}$ & {$[58,59]$} \\
\hline $\begin{array}{l}\text { Heatwaves, } \\
\text { droughts }\end{array}$ & $\begin{array}{l}\text { Increase in temperature due to } \\
\text { climatic change. }\end{array}$ & EN & EX & $\begin{array}{l}\text { MI, RE, CO, } \\
\text { IN, }\end{array}$ & {$[60,61]$} \\
\hline Water scarcity & $\begin{array}{l}\text { Lack of water to meet the demands } \\
\text { of operation. }\end{array}$ & EN & EX & MI, PR, IN & {$[62]$} \\
\hline Child/forced labor & $\begin{array}{l}\text { Depriving children of their childhood, } \\
\text { harmful to develop. }\end{array}$ & SO & IN & $\begin{array}{l}\text { MI, PR, AV, } \\
\text { SH }\end{array}$ & {$[63,64]$} \\
\hline Discrimination & Prejudicial treatment based on difference. & $\mathrm{SO}$ & IN & MI, PR, TR & {$[65]$} \\
\hline $\begin{array}{l}\text { Dangerous working } \\
\text { environment }\end{array}$ & $\begin{array}{l}\text { Working under unhealthy or } \\
\text { untrusting conditions. }\end{array}$ & SO & IN & $\begin{array}{l}\text { MI, PR, RE, } \\
\quad \mathrm{CO}\end{array}$ & {$[61,66]$} \\
\hline Inhumane treatment & Violating an individual's dignity. & SO & IN & MI, PR & [67] \\
\hline $\begin{array}{c}\text { Labor force } \\
\text { unavailability risk }\end{array}$ & $\begin{array}{c}\text { Lack of trained HR. Delays due to lack of } \\
\text { management expertise. Including } \\
\text { unavailability due to occupational } \\
\text { risk exposure. }\end{array}$ & SO & IN & $\begin{array}{l}\text { MI, PR, RE, } \\
\text { IN }\end{array}$ & [68] \\
\hline $\begin{array}{c}\text { Unethical treatment } \\
\text { of animals }\end{array}$ & Treat animals cruelly, cause suffering or pain. & SO & IN & MI, PR, RE & {$[69,70]$} \\
\hline
\end{tabular}


Table 1. Cont.

\begin{tabular}{|c|c|c|c|c|c|}
\hline $\begin{array}{l}\text { Risk (Sources and } \\
\text { Consequences) }\end{array}$ & Description & Dimension & Origins & Response & References \\
\hline $\begin{array}{l}\text { Excessive working } \\
\text { time }\end{array}$ & $\begin{array}{l}\text { Heavy workloads and job demand beyond } \\
\text { legal requirements. }\end{array}$ & SO & IN & $\begin{array}{l}\text { MI, PR, RE, } \\
\quad \mathrm{CO}\end{array}$ & [71] \\
\hline $\begin{array}{l}\text { Demographic } \\
\text { challenges }\end{array}$ & $\begin{array}{l}\text { Employment-related to immigration, } \\
\text { ageing and population growth. }\end{array}$ & SO & EX & MI & {$[72]$} \\
\hline Pandemic & $\begin{array}{l}\text { An epidemic over a wide area, } \\
\text { crossing boundaries. }\end{array}$ & $\mathrm{SO}$ & EX & PR, RT & [73] \\
\hline $\begin{array}{l}\text { Security risk/Social } \\
\text { Instability/unrest }\end{array}$ & $\begin{array}{l}\text { Strikes, work stoppages, street protests, } \\
\text { demonstrations, terrorism. Attacks on } \\
\text { installations. Equipment theft. Vandalism. }\end{array}$ & $\mathrm{SO}$ & EX & MI, RE, CO & {$[74,75]$} \\
\hline $\begin{array}{c}\text { Antitrust } \\
\text { claims/Price fixing }\end{array}$ & $\begin{array}{l}\text { Claims arising against a company that } \\
\text { violate competition laws (cartels, } \\
\text { predatory pricing). }\end{array}$ & $\mathrm{EC}$ & IN & $\begin{array}{l}\text { MI, PR, RE, } \\
\text { IN, AV }\end{array}$ & {$[76,77]$} \\
\hline Bribery/Corruption & $\begin{array}{l}\text { Offer (accept) a potential partner in exchange } \\
\text { for business benefit. }\end{array}$ & $\mathrm{EC}$ & IN & PR, IN & {$[77,78]$} \\
\hline Transport risk & $\begin{array}{l}\text { Breaks during transportation. Accidents. } \\
\text { Thefts. Damages. Natural disasters affecting } \\
\text { the transportation stage. }\end{array}$ & $\mathrm{EC}$ & IN & MI, PR, AV & {$[79,80]$} \\
\hline Third-party service & $\begin{array}{l}\text { Non-compliance of outsourced services. A } \\
\text { breach or lack of financing of contracted and } \\
\text { subcontracted suppliers. }\end{array}$ & $\begin{array}{l}\mathrm{EN} \\
\mathrm{SO} \\
\mathrm{EC}\end{array}$ & IN & $\begin{array}{l}\text { MI, PR, RE, } \\
\text { IN, CO }\end{array}$ & [81] \\
\hline $\begin{array}{l}\text { Technology and } \\
\text { innovation risk }\end{array}$ & $\begin{array}{c}\text { Inaccuracies in incapacity definition. } \\
\text { Technological obsolescence. Damage and } \\
\text { breakage attributable to design or } \\
\text { project sizing. }\end{array}$ & $\mathrm{EC}$ & IN & $\begin{array}{l}\text { MI, PR, RE, } \\
\text { IN, CO }\end{array}$ & {$[6,82,83]$} \\
\hline $\begin{array}{l}\text { Tax avoidance/ } \\
\text { evasion }\end{array}$ & $\begin{array}{l}\text { Illegal attempt to reduce the tax amount } \\
\text { payable by fraudulent means. }\end{array}$ & $\mathrm{EC}$ & IN & MI, PR & [84] \\
\hline $\begin{array}{l}\text { Boycotts/Public } \\
\text { opposition risk }\end{array}$ & $\begin{array}{l}\text { Not buying from, or dealing with, an } \\
\text { organization as a protest. Potential changes } \\
\text { in public opinion. Conflicts over land-use } \\
\text { restrictions. Changes in public policies } \\
\text { affecting nearby communities. }\end{array}$ & $\mathrm{EC}$ & EX & PR, RE, RT & {$[85,86]$} \\
\hline $\begin{array}{l}\text { Energy prices } \\
\text { volatility }\end{array}$ & $\begin{array}{l}\text { Unpredictable, continuous energy and fuel } \\
\text { price variation. }\end{array}$ & $\mathrm{EC}$ & EX & MI, IN, RT & {$[53,87]$} \\
\hline Financial Risk & $\begin{array}{l}\text { Sudden loss of a large part of the nominal } \\
\text { value of financial assets, lack and/or loss of } \\
\text { capital. Exchange rate variation. } \\
\text { Cost volatility. }\end{array}$ & $\mathrm{EC}$ & EX & MI, RT, & {$[88,89]$} \\
\hline Litigations & $\begin{array}{l}\text { Lawsuits against a company for } \\
\text { sustainability-related issues. }\end{array}$ & EC & EX & $\mathrm{PR}, \mathrm{CO}, \mathrm{AV}$ & [90] \\
\hline
\end{tabular}

Response-MI: mitigate; PR: prevent; RE: reduce; IN: insure; CO: control; AV: avoid; CP: cooperate; SH: share; TR: transfer; RT: retain. Dimension-EN: environmental; SO: social; EC: economic. Origins-IN: internal; EX: external.

One aspect that should be further developed in sustainability risk studies is the idea of a "potential event" [84]. A potential event, by definition, is the natural triggering of cumulative events. A supplier's misconduct related to sustainability may give rise to socalled event 1 that, when detected by interested parties, will lead to event 2 , which they can ultimately decide to communicate widely, in event 3 . In this way, suppliers' sustainability risks correspond to the cumulative probability of these events and their consequences [91]. Thus, suppliers' sustainability levels depend not only on the probability and immediate consequences of suppliers' misconduct, but also on factors related to their size and visibility in the market [92], and the location of supply bases [93]. It is also important to emphasize 
that a potential event implies that buyers do not react to the event, but only to the possibility of its occurrence.

In Table 1, risks factors are also categorized by responses adopted by companies. Sustainability risks can trigger stakeholders' adverse reactions, resulting in image and reputation damage for customers, or even generating boycotts or cancellations [11,13]. Such harmful reactions can lead to supply chain interruption, so it is necessary to distinguish suppliers' sustainability risks from traditional risks as known in the supply chain literature. A supply chain disruption results from internal or external unscheduled process failures, such as strikes or natural hazards [94]. Supplier sustainability risk is directly linked to stakeholders' adverse reactions [2,19], and can arise if buyers are held responsible by relevant stakeholders due to the inappropriate conduct of their suppliers, related to the natural environment or social communities [84].

\subsection{Risk Responses}

Risk mitigation is usually based on monitoring or collaboration strategies [95-97]. It can be considered that the general objective of supplier risk management, whether related to sustainability or not, is to address the occurrence probability of these risks and their consequences, verifying the generating sources and seeking to implement risk management strategies to protect the organization [84,98]. The risk management literature allows for the identification of distinct sustainability risk management strategies in these suppliers. For example, risk avoidance is a proactive strategy that involves eliminating risks when withdrawing from the situation in question [84,99], and this form of response corresponds to not performing an activity that may lead to exposure to risk. In supply chains, adopting practices such as not selecting suppliers that use unsustainable technologies or processes is a way to avoid exposure to this risk [100]. Another way to face risks is risk acceptance, a reactive strategy whereby buyers assume that suppliers simply retain the risk by not acting, but by budgeting for damage control, dealing with the potential risk event if it occurs [55]. This action involves accepting the potential damage incurred by a sustainability-related risk event in cases where the actual cost of other strategies would be greater than the total cost of the potential damage [101].

The practices and activities that collectively define the development of sustainable suppliers involve initiatives based on monitoring or collaboration [102-104]. Establishing a supplier development program to reduce the likelihood of environmental accidents is a common method. However, it can also involve actions to mitigate the severity of a sustainability-related risk, such as quickly responding to reports of unsustainable practices by a supplier. In this case, buyers generally collect and process information from suppliers, creating appropriate criteria that assess aspects related to sustainability in the context of incoming goods, and carrying out surveys and audits, demanding information on different dimensions of their social and ecological performance [105]. The results have been transcribed into the tables of this paper, which sought to identify patterns in the respondents' responses that would allow them to fit into the groups defined in [13]. Examples of risk responses are presented in Table 2.

The practices related to actual risks or combination risks and recommended strategies have been grouped using the risk management framework's response strategies:

i Insure (IN) - General insurance, protection of employees' health against natural catastrophes and disasters, and in operation, protect employees against pandemics, and develop a system to inform managers in a timely manner on litigation;

ii Retain (RT) -Accept risk if penalties are low and adapt to a new reality;

iii Prevent (PR)-Monitor CO2 footprint across the supply chain;

iv Reduce (RE) - Sustainable waste management, relationship with local communities, establish crisis team to deal with attacks, reduction in flexible hours, respond quickly to media or government reports, safety instructions and contingency plans, train employees and adopt new technology; 
v Mitigate (MI) - Have health procedures to protect staff, emergency plans for potential accidents, system to act swiftly in response to allegations, improve environmental audits, insure against infringements from customers/suppliers, invest in renewable energy sources, locate facility away from urban areas, respond swiftly to adverse reports, water recycling.

vi Cooperate (CP) - Build a flexible supply chain, work with suppliers to quickly determine potential consequences, close industry collaboration, continuously assess the water footprint, design products requiring less packaging, work with potential suppliers to interpret the law to identify risk sources;

vii Avoid (AV) - Locate facility away from urban areas, use clean energy, avoid polluting suppliers, avoid countries with poor transparency record, avoid investment in regions with a poor record for child labor, avoid investment in unstable regions;

viii Share (SH) - Conduct sustainability audit with critical suppliers; work closely with suppliers to limit child labor;

ix Transfer (TR)—Employ legal services to deal with equal opportunities, engage governments and financial institutions to support liquidity, hedge against volatility jointly; x Control (CO)—Acquire ISO14001 and ISO26000 certificate.

Some solutions can be seen in the literature that companies can adopt to deal with the risks related to sustainability in the supply chain.

Table 2. Risk responses.

\begin{tabular}{cr}
\hline Original Item & Example \\
\hline Insure $(\mathrm{IN})$ & Insurance and develop an internal information system. \\
\hline Retain $(\mathrm{RT})$ & Accept risk if penalties are low, adapt to a new reality. \\
\hline Prevent $(\mathrm{PR})$ & Monitor CO2 footprint across the supply chain. \\
\hline Reduce $(\mathrm{RE})$ & Sustainable waste management by adoption of new technology. \\
\hline Mitigate $(\mathrm{MI})$ & Plans for potential accidents, improve environmental audits. \\
\hline Cooperate $(\mathrm{CP})$ & Build flexible supply chain; close industry collaboration. \\
\hline Avoid $(\mathrm{AV})$ & Avoid countries with poor transparency records, and with child labor. \\
\hline Share $(\mathrm{SH})$ & Sustainability audit with critical suppliers. \\
\hline Transfer $(\mathrm{TR})$ & Employ legal services to deal with equal opportunities. \\
\hline Control $(\mathrm{CO})$ & Acquire environmental and social certification. \\
\hline Respons
\end{tabular}

Response-insure (IN); retain (RT); prevent (PR); reduce (RE); mitigate (MI); cooporate (CP); avoid (AV); share (SH); transfer (TR); control (CO).

How companies respond to social demands related to sustainability, as are the focus here, can say a lot about how these companies can benefit from competitive advantages in terms of cost savings [106] or different leadership advantages [2]. Some studies indicate a direct relationship between sustainability performance and financial results [18]. It is therefore appropriate, based on empirical studies, to identify the processes that generate sustainability risks in supply chains [2] and the operational approaches from which companies could enjoy benefits, with respect to how markets understand sustainability, and creating value for companies, while differentiating their sustainability practices [107].

A study of a relevant segment of the Brazilian economy is necessary to understand how sustainability risks factors are related, how they can be ranked, how companies in Brazil manage these risks, and, above all, how these companies understand their role as a propagator of sustainability in supply chains. 


\section{Methods}

\subsection{General Context}

To approach the research aims that guided this study, the steps shown in Figure 1 were followed. A methodological strategy was used according to a positivist philosophy with a deductive approach, based on qualitative and quantitative methods [108]. Initially, a literature survey was conducted to identify the sustainability risk in the supply chain.

Subsequently, expert discussions were used to assess these risks and determine which ones are most relevant to the context of the cosmetics supply chain. The same experts were asked to outline the contextual relationships between the selected risks.

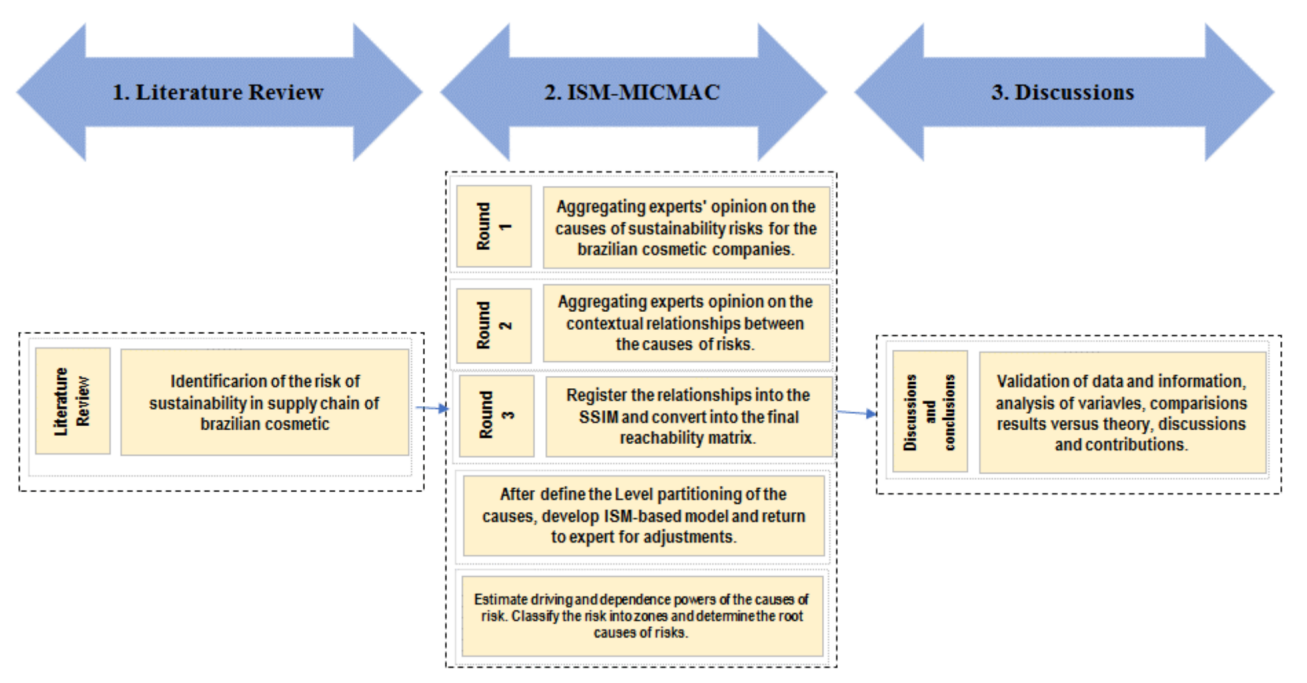

Figure 1. Research methods adopted in this study.

The approach adopted in this study focuses on the operational-level actions related to sustainability risks that company managers can take in order to benefit their supply chain. Thus, the scope of management risk is here limited to purchasing and supply management functions, which do not involve broad corporate policies. Customer-supplier management is the area of analysis, approached from a supplier-sustained risk perspective. The study does not include NGOs, government authorities or other stakeholders' interactions, focusing mainly on focus companies with supplier interactions. Finally, the study emphasizes risk management, not risk consequences, as the strategies assessed are not reactions to a crisis but rather decisions taken given the current operational context.

\subsection{Focus Group}

Based on experts' opinions, sustainability risks that affect Brazilian cosmetic companies' supply chains, and how these risks are related to each other, were identified. The experts were expected to provide high-quality information on the subject under study and, therefore, were selected according to specific criteria [109]. Ten experts were selected and invited to contribute to the panel to discuss sustainability risks. The sampling was guided by their professional experience in managing Brazilian companies in the cosmetic sector, and the access one of the study's authors has; it can be classified as a convenience sample.

These individuals were expected to offer a holistic view of sustainability risks along the supply chain, related to companies that import, produce, distribute, market and export different cosmetic products. The experts invited to participate are shown in Table 3 , and their opinions were collected at three different time points.

The encounters with experts were moderated by one of the authors of this work. It was up to this moderator to guide the discussion of general and specific topics, seeking consensus and reducing dilemmas that could arise with these experts.

The experts' contributions were divided into different moments after accepting the challenge: (i) the experts received an email with a list of 30 risks found in the literature 
(with their definitions), in order to prepare the discussion; (ii) a first face-to-face meeting was scheduled, in which some of them participated remotely, and the participants were encouraged to speak openly about the definitions of the risks and their suitability to the context of the cosmetic sector, then asked to include other risks factors or definitions that perhaps could better explain the reality of companies in this segment, which the literature could have disregarded; (iii) a third moment was scheduled to continue the discussions, after a preliminary version of the relationships matrix was generated, indicating the relationships hitherto identified among the selected risks. The discussions generated consensus around a list of ten risks, and the final list was voted on by all the experts involved.

Table 3. Profile of the experts.

\begin{tabular}{cccc}
\hline Expert & Type of Activity & Designation & Years of Working Experience \\
\hline 1 & Cosmetic Producer & Senior Operations Manager & 15 \\
2 & Cosmetic Producer & Operations Manager & 12 \\
3 & Logistics Operator & Logistics Manager & 9 \\
4 & Retailer & Procurement Manager & 11 \\
5 & Cosmetic Supply Chain Consulting & SC Consulting & 17 \\
6 & Cosmetic Producer & Financial Director & 11 \\
7 & Cosmetic Producer & Operations Manager & 8 \\
8 & Cosmetic Producer & Logistics Analyst & 13 \\
9 & Retailer & Procurement Manager & 19 \\
10 & Cosmetic Supply Chain Consulting & Operational Director & 27 \\
\hline
\end{tabular}

The moderator asked the experts a set of previously defined questions to guide the discussion: (i) Are there any risks applicable to supply chains in the cosmetic sector? Which ones? (ii) Are the definitions presented by the literature review adequate? If not, what should be changed or inserted in the set of definitions presented? (iii) Are there similarities between the risks? If so, which ones should be merged and what kind of relationship is established between them?

Additionally, experts were invited to participate in a discussion involving the responses to each of these risks, and based on the findings in the literature, a list of items was presented on how the literature presents the treatments for each of the risks recognized and which treatments they have already had to adopt, given the indicated risks.

The items understood by the experts as sustainability risks in Brazilian cosmetic companies' supply chains were presented to the panel. Then, the moderator explained the operation of the ISM matrix (see Sections 3.3 and 3.4 headings). The meaning of each relationship code was then manually filled in to denote the existing relationships between the factors, with experts indicating their relationships amongst each-if there was a relationship, and if so, what the sign of that relationship is.

After implementing the ISM methodology, the hierarchical structure was sent by email to the experts so that they could contribute again, this time evaluating the results of the meetings, forming a definitive list and correcting the inconsistencies that some relationships could present. This process was carried out with a panel, which allowed for choosing the preferred relationship and then discussing doubts. The final chart was sent to experts, and they were invited to a third discussion to assess inconsistencies in the model.

After identifying the risks and their relationships, the final matrix was presented and discussed with specialists; an attempt was made to identify the primary responses adopted for each risk involved.

\subsection{Interpretive Structural Modeling}

Structured interpretative approaches allow for organizing relationships between the variables of complex research problems [31]. Structured approaches can translate mental models, which often have little clarity in visible and well-defined systems, helping users to understand the variables of a system, its hierarchy, and its relationships [31]. It is 
possible to apply the interpretive matrix directly in structural modeling, transforming the codes assigned to each relation into targeted and non-directed binary information. Interpreting nodes and links in the structural model can offer valuable information about the system under study, which is more applicable in practical situations. Explanations and an understanding of some of the structures, relationships and possible interpretations can be obtained.

The basic ISM process was presented by [110], indicating the steps for ISM development: (i) identifying the problem variables; (ii) developing the contextual relationship between risks; (iii) interpreting the logic in the hidden relationship between these risks; (iv) peer comparison-developing the auto structural interaction matrix; (v) creating the accessibility matrix and checking transitivity; (vi) matrix-level partitions to understand the positioning of risks and which levels they belong to; (vii) interaction matrix diagram; (viii) ISM development through a relationships matrix between risks.

\subsection{Classification of Risks: MICMAC Analysis}

To complement the ISM analysis, MICMAC was used. This is a tool adopted in complex situations, which involves modeling critical success factors, as in the case of sustainability risks. MICMAC complements ISM structural analysis since it can define clusters, grouping variables with homogeneous characteristics based on an established criterion. Some studies use a combined ISM-MICMAC methodology to assess the relationship between supply chain risks, even in different sectors, such as the Brazilian energy sector, identifying which variables can influence or be influenced [33].

Different applications for this tool are identified in the literature, such as assessing the mutual relationship between critical variables for the implementation of knowledge management in industries [111]; determining variables of a supply chain performance measurement system to increase efficiency and effectiveness [112]; the training of information technology in supply chains [113]; the interrelation of facilitators of flexibility in the global supply chain [114]; risk relationship [104].

With MICMAC analysis, it is possible to analyze factors' dependence and driving power [115] so as to identify the risks responsible for driving the entire system. A value of " 1 " in a cell represents the driving power and the dependence of rows and columns, respectively, for each factor. This is a graphic technique of representing factors, according to the power of direction and dependence, allowing for grouping by clusters.

Risks are interrelated, and experts were asked to assess these contextual relationships in the cosmetic supply chain. To derive and analyze the relationships between the risks, the ISM criteria were outlined for the experts: (i) $\mathrm{V}=$ risk $\mathrm{i}$ influences risk j; (ii) $\mathrm{A}=$ risk $\mathrm{j}$ influences risk $\mathrm{i}$; (iii) $\mathrm{X}=$ risks $\mathrm{i}$ and $\mathrm{j}$ are mutually influenced; and (iv) $\mathrm{O}=$ risks $\mathrm{i}$ and $\mathrm{j}$ are not related. In cases of impasse, the majority ruled.

\section{Results}

\subsection{Identification of the Risks Factors}

The first stage of the ISM methodology determines supply chains' sustainability risks to be investigated, obtained through the first discussion with experts. The experts in Table 2 were invited to assess which risks, gathered from the literature and listed in Table 1, are relevant to the Brazilian cosmetics segment, which were then considered in this study. A risk was selected only when most experts agreed on its applicability to the cosmetic supply chain. Otherwise, the risk was left out and considered as only having a minor role. As a result, ten risk factors emerged from the discussion, making up a final list for the next step:

Financial risks (R1) - Corresponds to the risks related to losing a large part of a company's financial assets' nominal value, which can lead to capital loss, and in turn can be caused by an exchange variation, increased costs, fines for failure to meet sustainability standards, and other factors. This risk may present itself in any of the three dimensions of sustainability $[88,89]$; 
Labor force risks (R2) - This type of risk is associated with absenteeism, or unexcused absence, the lack of training for the workforce, delays, or production losses due to failure to manage employee training, or even unavailability due to occupational risk exposure [68]. It is a risk that is classified in the social dimension and is usually internal in the supply chain;

Technology and innovation risks (R3) - This item relates to the impacts on business management systems, which are crucial for monitoring sustainability in the chain, primarily due to the high volume of information processed. It is increasingly perceived that companies and supply chains require structural technology to maintain full functioning, whether this refers to machine and network availability or security, and this is becoming increasingly subject to risk, with losses of information due to data hijacking (security breaches) or the inadequate handling of databases (lack of governance policy). These are some of the errors related to capacity, technological obsolescence, or damage derived from the inadequate dimensioning of "technology and innovation risks" [6,82,83], which can lead to failures in the management of the sustainability of suppliers;

Boycotts risks (R4) - This can result in a lack of sales due to protests against company actions or practices. These may be attributed to organizational behaviors, which have a negative impact on the brand and affect public opinion. These risks can also result from disagreements on sustainability issues, conflict over land-use restrictions, or changes in public policies for nearby communities $[10,11,86]$;

Transportation risks (R5)-These risks can manifest themselves as damages that occur during item transportation between the companies involved in the process of materializing the item. Accidents with the cargo or the vehicle may occur, such as theft, damage, or even natural disasters, which affect the integrity of the company's assets at the transportation stage. Transport risks are internal to supply chains and directly involve the economic dimension of sustainability $[79,80,116]$;

Natural hazard risks (R6) - This type of risk is associated with disruptions caused by disasters, such as earthquakes, hurricanes, or severe weather conditions. Many regions are overlooked at the expense of others, as they have higher chances of major natural disasters. Often, if enough occurrences are recorded, insurance will not be available or will be unviable. This type of risk is external to the supply chain, and is linked to the environmental dimension [58];

Legal and responsibility risks (R7) - In this risk, there is a failure to comply with environmental, labor, or financial regulations. This risk can include several joint liabilities that a focal company bears in relation to the authorities regarding its service providers. A company can be held responsible for the failures of its suppliers when they do not meet the expected sustainability standards. The payment of unfair wages can be one such aspect that involves a focal company [52,115];

Third-party service risks (R8) - When hiring a third-party service, it is expected that the service will be offered within the context specific standards to be met, according to a set of contractual items. When a service provider does not meet these requirements, service non-compliance is a significant risk to focus companies. It also includes suppliers' violation, or lack, of financial conditions when dealing with its commitments, either contracted or subcontracted [81];

Ecological damage risks (R9)-A supply chain, through its operations and products, can produce air, water or soil contamination. In general, these risks are manifested via interruptions in operations caused by ecological issues, potentially linked to interference with the habitats of threatened or protected species [43,48];

Security risks (R10) - These risks are associated with general safety, and can come from social instability, agitation, strikes, stoppages, street protests, and demonstrations. Another security risk type manifests in attacks on installations, the theft of equipment, and vandalism $[74,75]$. 


\subsection{Structural Self-Interaction Matrix}

Direct relationships are shown in the Structural Self-Interaction Matrix (SSIM) in Table 4.

Table 4. Structural Self-Interaction Matrix.

\begin{tabular}{ccccccccccc}
\hline C[i/j] & R1 & R2 & R3 & R4 & R5 & R6 & R7 & R8 & R9 & R10 \\
\hline R1 & - & A & A & A & A & A & A & A & A & A \\
R2 & & - & O & V & O & A & A & X & O & X \\
R3 & & & - & O & V & O & O & O & O & O \\
R4 & & & & - & A & O & A & A & A & A \\
R5 & & & & & - & O & A & V & V & O \\
R6 & & & & & & - & A & A & V & A \\
R7 & & & & & & & - & O & O & O \\
R8 & & & & & & & & - & V & V \\
R9 & & & & & & & & & - & O \\
R10 & & & & & & & & & & - \\
\hline
\end{tabular}

Note: C[i/j] represents the risk in line i or in column j.R1: Financial. R2: Labor Force. R3: Technology and innovation. R4: Boycott. R5: Transportation. R6: Natural hazard. R7: Legal and responsibility, R8: Third-party service. R9: Ecological damage. R10: Security.

Next, the SSIM was transformed into an Initial Reachability Matrix (IRM), according to Table 5, replacing V $(i=1$ e $j=0), A(i=0$ e $j=1), X(i=1$ e $j=1)$ and $O(i=0$ and $j=0)$.

Then, the SSIM was transformed into a binary matrix (hereafter called the initial reachability matrix, IRM), as shown in Table 4, by substituting $\mathrm{V}, \mathrm{A}, \mathrm{X}$ and $\mathrm{O}$ with 1 s and 0 s, according to the following rules:

$i$ If the $(i, j)$ input in SSIM is $V$, then the $(i, j)$ input in IRM becomes 1 and the $(j, i)$ input becomes 0 ;

ii If the (i, j) input in SSIM is $A$, then the $(i, j)$ input in IRM becomes 0 and the $(j, i)$ input becomes 1 ;

iii If the $(i, j)$ input in SSIM is $X$, then the $(i, j)$ and $(j, i)$ inputs in IRM become 1 ;

iv If the $(i, j)$ input in SSIM is $O$, then the $(i, j)$ and $(j, i)$ inputs in IRM become 0 .

To avoid human error, MS Excel was used, with a programmed function (Macro) to automatically check the transitivity of indirect relations. If cause " $\mathrm{i}$ " is directly related to cause " $\mathrm{j}$ ", and cause " $\mathrm{j}$ " is directly related to cause " $k$ ", then causes " $\mathrm{i}$ " and " $\mathrm{k}$ " are indirectly related, by means of cause $j$, and if the input $(i, k)$ of the IRM is 0 , then it must be replaced by a $1^{*}$.

Table 5. Initial Reachability Matrix.

\begin{tabular}{ccccccccccc}
\hline $\mathbf{C}[\mathbf{i} / \mathbf{j}]$ & $\mathbf{R} 1$ & $\mathbf{R} 2$ & $\mathbf{R 3}$ & $\mathbf{R} 4$ & $\mathbf{R} 5$ & $\mathbf{R 6}$ & $\mathbf{R 7}$ & $\mathbf{R} 8$ & $\mathbf{R 9}$ & $\mathbf{R} 10$ \\
\hline R1 & 1 & 0 & 0 & 0 & 0 & 0 & 0 & 0 & 0 & 0 \\
R2 & 1 & 1 & 0 & 1 & 0 & 0 & 0 & 1 & 0 & 1 \\
R3 & 1 & 0 & 1 & 0 & 1 & 0 & 0 & 0 & 0 & 0 \\
R4 & 1 & 0 & 0 & 1 & 0 & 0 & 0 & 0 & 0 & 0 \\
R5 & 1 & 0 & 0 & 1 & 1 & 0 & 0 & 1 & 1 & 0 \\
R6 & 1 & 1 & 0 & 0 & 0 & 1 & 0 & 0 & 1 & 0 \\
R7 & 1 & 1 & 0 & 1 & 1 & 1 & 1 & 0 & 0 & 0 \\
R8 & 1 & 1 & 0 & 1 & 0 & 1 & 0 & 1 & 1 & 1 \\
R9 & 1 & 0 & 0 & 1 & 0 & 0 & 0 & 0 & 1 & 0 \\
R10 & 1 & 1 & 0 & 1 & 0 & 1 & 0 & 0 & 0 & 1 \\
\hline
\end{tabular}

Note: $\mathrm{C}[\mathrm{i} / \mathrm{j}]$ represents the risk in line i or column j. R1: Financial. R2: Labor force. R3: Technology and innovation R4: Boycott. R5: Transportation. R6: Natural hazard. R7: Legal and responsibility. R8: Third-party service. R9: Ecological damage. R10: Security.

The IRM was subsequently checked for transitivity, and, in the case of this type of relationship, the concept was applied to par $i$ and $j$ of the matrix, as indicated [111]. The FRM is obtained by replacing 0 with $1^{*}$, in the case of the transitivity verification (Table 6 ), 
responsible for all relationships (direct and indirect) between the sustainability risks. The transitivity was found using MS Excel, with a programmed function (Macro) that identified indirect relationships automatically $[31,32,34]$.

Table 6. Final Reachability Matrix.

\begin{tabular}{cccccccccccc}
\hline C[i/j] & R1 & R2 & R3 & R4 & R5 & R6 & R7 & R8 & R9 & R10 & DVP \\
\hline R1 & 1 & 0 & 0 & 0 & 0 & 0 & 0 & 0 & 0 & 0 & 1 \\
R2 & 1 & 1 & 0 & 1 & 0 & $1^{*}$ & 0 & 1 & $1^{*}$ & 1 & 7 \\
R3 & 1 & $1^{*}$ & 1 & $1^{*}$ & 1 & $1^{*}$ & 0 & $1^{*}$ & $1^{*}$ & $1^{*}$ & 9 \\
R4 & 1 & 0 & 0 & 1 & 0 & 0 & 0 & 0 & 0 & 0 & 2 \\
R5 & 1 & $1^{*}$ & 0 & 1 & 1 & $1^{*}$ & 0 & 1 & 1 & $1^{*}$ & 8 \\
R6 & 1 & 1 & 0 & $1^{*}$ & 0 & 1 & 0 & $1^{*}$ & 1 & $1^{*}$ & 7 \\
R7 & 1 & 1 & 0 & 1 & 1 & 1 & 1 & $1^{*}$ & $1^{*}$ & $1^{*}$ & 9 \\
R8 & 1 & 1 & 0 & 1 & 0 & 1 & 0 & 1 & 1 & 1 & 7 \\
R9 & 1 & 0 & 0 & 1 & 0 & 0 & 0 & 0 & 1 & 0 & 3 \\
R10 & 1 & 1 & 0 & 1 & 0 & 1 & 0 & $1^{*}$ & $1^{*}$ & 1 & 7 \\
\hline DPP & 10 & 7 & 1 & 9 & 3 & 7 & 1 & 7 & 8 & 7 &
\end{tabular}

Note: $\mathrm{C}[\mathrm{i} / \mathrm{j}]$ represents the risk in line $\mathrm{i}$ or column $\mathrm{j}$; DPP—-dependence power; DVP—Driving power. $\mathrm{R} 1$ : Financial. R2: Labor force. R3: Technology and innovation. R4: Boycott. R5: Transportation. R6: Natural hazard. R7: Legal and responsibility. R8: Third-party service. R9: Ecological damage. R10: Security.

Driving and dependence powers were also calculated to assist in the definition of the levels of the variables through level partitioning. For each variable, the accessibility set, the background set and the intersection set were found to assess the levels of the variables.

The accessibility set is the sum of entries equal to 1 for each row (indicating that variable $i$ influences variable $j$ ). The antecedent set is the sum of entries equal to 1 for each column (indicating that variable $i$ is influenced by variable $j$ ). In addition, the intersection set comprises the duplicate variables of the accessibility and antecedent sets. In cases wherein the set of intersection is equal to the set of reachability, the variable is assigned to the level of that iteration. The variables assigned to a level are removed from the other accessibility and intersection sets for the next iteration. The exact process is applied until all variables are partitioned into levels.

The partitioning level results of the ten risks (Table 7) under study and the risk considered to be of the highest level in the ISM-based model give the "financial risks", followed by "boycott risks" and "ecological damage risks", and after the fourth interaction the "labor force risks", "third-party service risks", "natural hazard risks" and "security risks" appear. After the fifth interaction, "transport risks" are shown, and finally, the lower level of the ISM-based model includes "technology and innovation risks" and "legal and responsibility risks".

Table 7. Level partitioning results.

\begin{tabular}{ccccc}
\hline Risks & Reachability Set & Antecedent Set & Intersection 1 & Level \\
\hline Risks & Reachability Set & Antecedent Set & Intersection 1 & Level \\
\hline R1 & $\{1\}$ & $\{1,2,3,4,5,6,7,8,9,10\}$ & $\{1\}$ & I \\
R2 & $\{1,2,4,6,8,9,10\}$ & $\{2,3,5,6,7,8,10\}$ & $\{2,6,8,10\}$ & \\
R3 & $\{1,2,3,4,5,6,8,9,10\}$ & $\{3\}$ & $\{3\}$ & \\
R4 & $\{1,4\}$ & $\{2,3,4,5,6,7,8,10\}$ & $\{5\}$ & \\
R5 & $\{1,2,4,5,6,8,9,10\}$ & $\{3,5,7\}$ & $\{2,6,8,10\}$ & \\
R6 & $\{1,2,4,6,8,9,10\}$ & $\{2,3,5,6,7,8,10\}$ & $\{7\}$ & \\
R7 & $\{1,2,4,5,6,7,8,9,10\}$ & $\{7\}$ & $\{2,6,8,9,10\}$ & \\
R8 & $\{1,2,4,6,8,9,10\}$ & $\{2,3,5,6,7,8,9,10\}$ & $\{9\}$ & \\
R9 & $\{1,4,9\}$ & $\{2,3,5,6,7,8,9,10\}$ & $\{2,6,8,9,10\}$ & \\
R10 & $\{1,2,4,6,8,9,10\}$ & $\{2,3,5,6,7,8,9,10\}$ & & \\
\hline
\end{tabular}


Table 7. Cont.

\begin{tabular}{|c|c|c|c|c|}
\hline Risks & Reachability Set & Antecedent Set & Intersection 1 & Level \\
\hline Risks & Reachability Set & Antecedent Set & Intersection 2 & Level \\
\hline $\mathrm{R} 2$ & $\{2,4,6,8,9,10\}$ & $\{2,3,5,6,7,8,10\}$ & $\{2,6,8,10\}$ & \\
\hline $\mathrm{R} 3$ & $\{2,3,4,5,6,8,9,10\}$ & $\{3\}$ & $\{3\}$ & \\
\hline $\mathrm{R} 4$ & $\{4\}$ & $\{2,3,4,5,6,7,8,10\}$ & $\{4\}$ & II \\
\hline $\mathrm{R} 5$ & $\{2,4,5,6,8,9,10\}$ & $\{3,5,7\}$ & $\{5\}$ & \\
\hline R6 & $\{2,4,6,8,9,10\}$ & $\{2,3,5,6,7,8,10\}$ & $\{2,6,8,10\}$ & \\
\hline R7 & $\{2,4,5,6,7,8,9,10\}$ & $\{7\}$ & $\{7\}$ & \\
\hline R8 & $\{2,4,6,8,9,10\}$ & $\{2,3,5,6,7,8,9,10\}$ & $\{2,6,8,9,10\}$ & \\
\hline R9 & $\{4,9\}$ & $\{2,3,5,6,7,8,9,10\}$ & $\{9\}$ & \\
\hline R10 & $\{2,4,6,8,9,10\}$ & $\{2,3,5,6,7,8,9,10\}$ & $\{2,6,8,9,10\}$ & \\
\hline Risks & Reachability Set & Antecedent Set & Intersection 3 & Level \\
\hline $\mathrm{R} 2$ & $\{2,6,8,9,10\}$ & $\{2,3,5,6,7,8,10\}$ & $\{2,6,8,10\}$ & \\
\hline R3 & $\{2,3,5,6,8,9,10\}$ & $\{3\}$ & $\{3\}$ & \\
\hline R5 & $\{2,5,6,8,9,10\}$ & $\{3,5,7\}$ & $\{5\}$ & \\
\hline R6 & $\{2,6,8,9,10\}$ & $\{2,3,5,6,7,8,10\}$ & $\{2,6,8,10\}$ & \\
\hline R7 & $\{2,5,6,7,8,9,10\}$ & $\{7\}$ & $\{7\}$ & \\
\hline $\mathrm{R} 8$ & $\{2,6,8,9,10\}$ & $\{2,3,5,6,7,8,9,10\}$ & $\{2,6,8,9,10\}$ & \\
\hline R9 & $\{9\}$ & $\{2,3,5,6,7,8,9,10\}$ & $\{9\}$ & III \\
\hline R10 & $\{2,6,8,9,10\}$ & $\{2,3,5,6,7,8,9,10\}$ & $\{2,6,8,9,10\}$ & \\
\hline Risks & Reachability Set & Antecedent Set & Intersection 4 & Level \\
\hline $\mathrm{R} 2$ & $\{2,6,8,10\}$ & $\{2,3,5,6,7,8,10\}$ & $\{2,6,8,10\}$ & IV \\
\hline R3 & $\{2,3,5,6,8,10\}$ & $\{3\}$ & $\{3\}$ & \\
\hline R5 & $\{2,5,6,8,10\}$ & $\{3,5,7\}$ & $\{5\}$ & \\
\hline R6 & $\{2,6,8,10\}$ & $\{2,3,5,6,7,8,10\}$ & $\{2,6,8,10\}$ & IV \\
\hline $\mathrm{R7}$ & $\{2,5,6,7,8,10\}$ & $\{7\}$ & $\{7\}$ & \\
\hline $\mathrm{R} 8$ & $\{2,6,8,10\}$ & $\{2,3,5,6,7,8,10\}$ & $\{2,6,8,10\}$ & IV \\
\hline R10 & $\{2,6,8,10\}$ & $\{2,3,5,6,7,8,10\}$ & $\{2,6,8,10\}$ & IV \\
\hline Risks & Reachability Set & Antecedent Set & Intersection 5 & Level \\
\hline $\mathrm{R} 3$ & $\{3,5\}$ & $\{3\}$ & $\{3\}$ & \\
\hline R5 & $\{5\}$ & $\{3,5,7\}$ & $\{5\}$ & $\mathbf{V}$ \\
\hline R7 & $\{5,7\}$ & $\{7\}$ & $\{7\}$ & \\
\hline Risks & Reachability Set & Antecedent Set & Intersection 6 & Level \\
\hline $\mathrm{R} 3$ & $\{3\}$ & $\{3\}$ & $\{3\}$ & VI \\
\hline R7 & $\{7\}$ & $\{7\}$ & $\{7\}$ & VI \\
\hline
\end{tabular}

R1: Financial. R2: Labor force. R3: Technology and innovation. R4: Boycott. R5: Transportation. R6: Natural hazard. R7: Legal and responsibility. R8: Third-party service. R9: Ecological damage. R10: Security.

\subsection{ISM-Based Model}

The graph shown in Figure 2 indicates the variables distributed vertically and horizontally, according to the level partitioning. If variable $i$ influences variable $j$ in the initial accessibility matrix, an arrow will be used, pointing from $i$ to $j$, to show the direct influence between these variables. The ISM-based model shown in Figure 2 demonstrates the hierarchical structure of risks and highlights their interrelationships.

The graph was generated by organizing the ten risks according to the level partitioning (Table 6) and connecting the risks according to the initial accessibility matrix (Table 4). The experts did not identify any inconsistencies.

The levels of different risks in the ISM-based model are shown visually to help understand their impact of reducing risks in the cosmetic supply chains (Figure 2). "Financial risks" are influenced by all other risks. "Financial risks" involve the nominal value of assets loss, generated by fines or non-compliance with legal obligations, whether by the company or by supply chain partners [88,89]. 


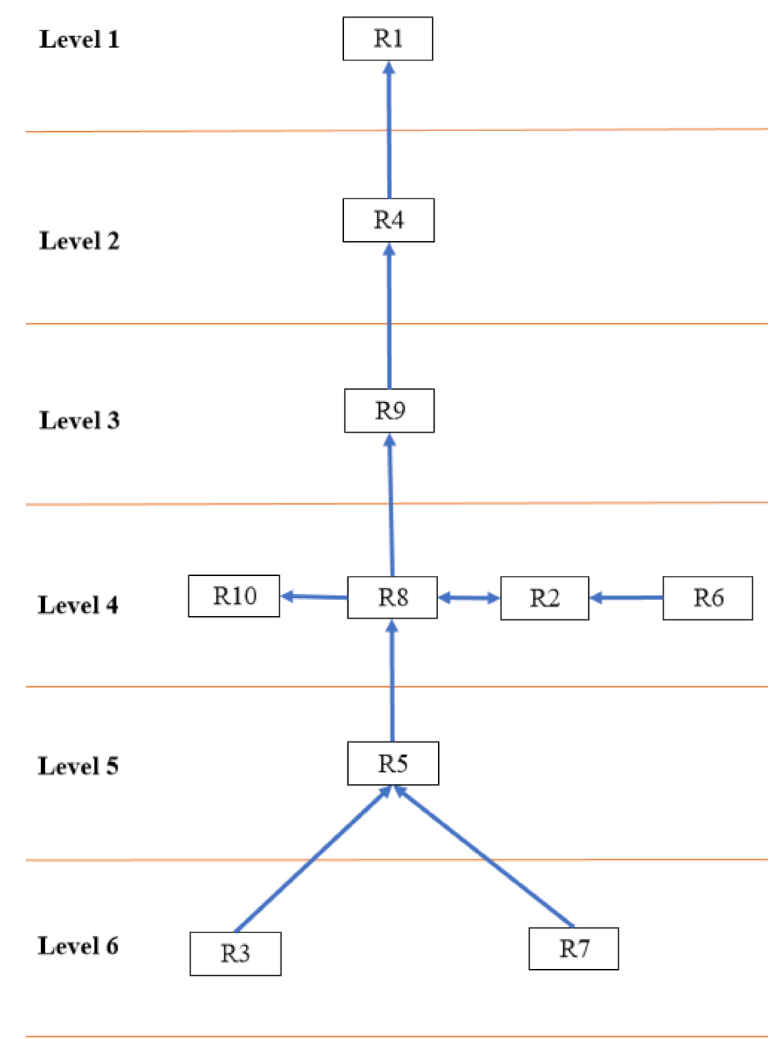

Figure 2. ISM-based model of risk supply chains. (R1: Financial. R2: Labor force. R3: Technology and innovation. R4: Boycott. R5: Transportation. R6: Natural hazard. R7: Legal and responsibility. R8: Third-party service. R9: Ecological damage. R10: Security).

"Boycott risks" appear at the second level, which means that this risk can influence the level one risk, and is influenced by the others and so on. This risk is represented in the refusal to purchase company products or services as a form of protest for their actions or practices, their inappropriate behavior in the eyes of public opinion, and their non-compliance with aspects of sustainability, among other things $[85,86]$.

After six iterations, the lower level of the ISM-based model was found, namely "technology and innovation risks" and "legal and responsibility risks", which have the most significant capacity to influence the entire system. This is the essential contribution of methodologies such as ISM. The hierarchy allows professionals to implement actions to eliminate risks of higher levels, which will potentially affect the entire system. In the case of level six, it will allow for eliminating risks throughout the system at lower levels. In general, risks at higher levels will potentially eliminate or affect risks at lower levels.

\subsection{MICMAC Analysis}

The MICMAC influence map represents the cluster with homogeneous risk variables. The variables are arranged in four zones in the influence map, represented by quadrants, according to their driving force and dependence. These zones represent the factors independent (Z1), autonomous (Z2), linkage (Z3) and dependent (Z4).

The MICMAC analysis is based on the strength of the relationships between risk variables in this study. As a result of the connection levels, an influence map was obtained (Figure 3). This divides risk variables into four zones, according to driving power and dependence. Driving power is the variable's ability to carry risks to or from other variables, while dependency power is the ability to absorb risks from other risk variables [33]. In the risk model, it appears that the variables occupy three of the four possible quadrants. The areas where risk factors appeared are: 
$\mathrm{Z1}$, independent factors-There are three risk variables in this zone. These variables are not very dependent, but they have a greater influence capacity in the system as a whole. They include "technology and innovation risks", "transportation risks", and "legal and responsibility risks". Any change in these risk factors would affect the entire system. Understanding which variables can be prioritized to develop mitigation strategies by companies in this area is crucial, serving as an essential starting point for actions;

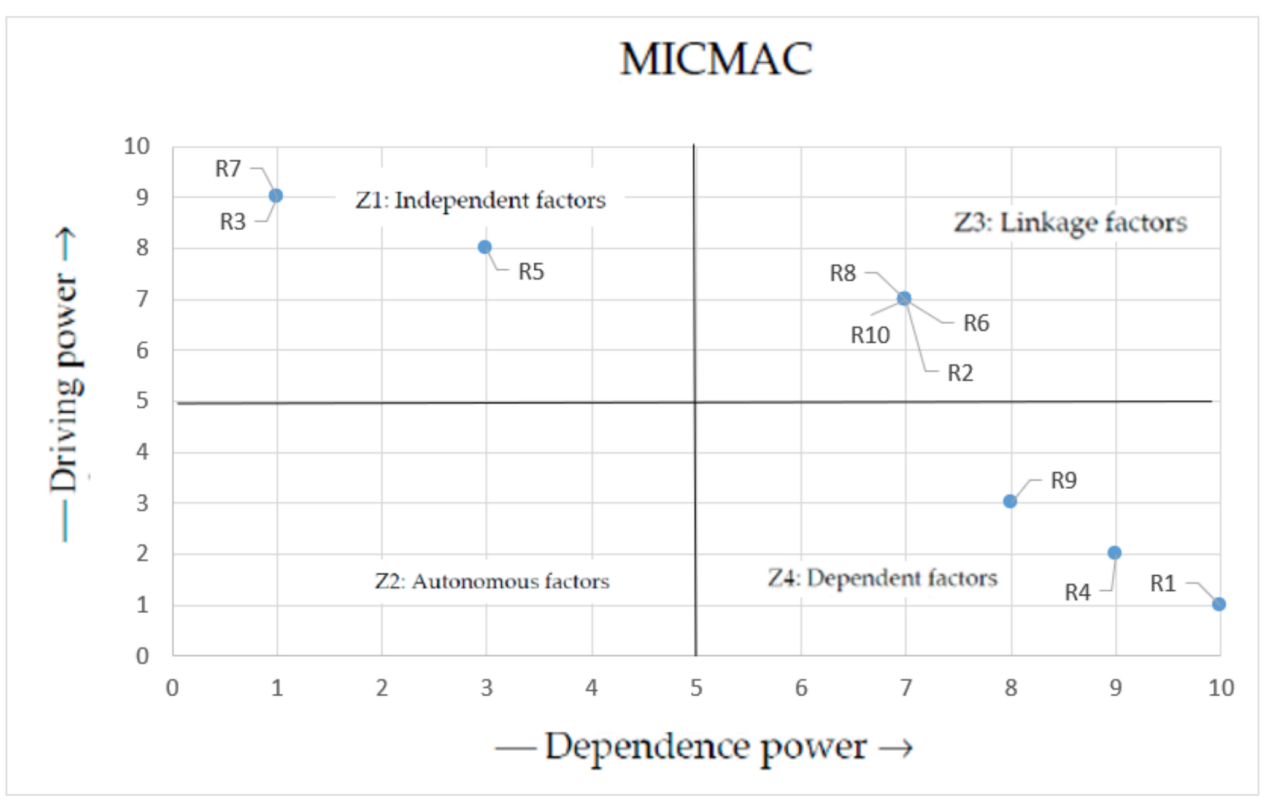

Figure 3. Driving and dependence influence matrix. (R1: Financial. R2: Labor force. R3: Technology and innovation. R4: Boycott. R5: Transportation. R6: Natural hazard. R7: Legal and responsibility, R8: Third-party service. R9: Ecological damage. R10: Security).

Z3, linkage factors-This zone is characterized by more conductive and dependent risk factors. Variables are affected by changes in the system, but simultaneously also affect the system. These risk variables are usually positioned in the middle of the model, linking the upper and lower levels. Four risk factors were identified in this zone, namely: "labor force risks", "natural hazard risks", "third-party service risks", and "security risks". A change in these risk variables can lead to instability in the system;

Z4, dependent factors-Three risk factors were identified, namely, "financial risks", "boycott risks", and "ecological damage risks". These are characterized by their high dependence, absorbing changes in the system more efficiently, while at the same time demonstrating less conductivity. These variables can be used as indicators of system stability because observing changes in these variables can indicate other factors that affect system stability.

No risks were identified in the $\mathrm{Z} 2$ quadrant of the so-called autonomous factors.

\subsection{Risk Responses}

The last step of the approach using specialists in the risk management process was the survey of the most used strategies to reduce or eliminate risk factors. Managers were asked to identify the methods most frequently used in their experience to deal with sustainability risks. The results have been transcribed in the tables of this research, which sought to identify patterns in the respondents' responses that would allow them to fit into the groups defined in [13]. The practices in response to actual risks or combinations of risks and recommended strategies were then grouped using the risk management framework's response strategies: insure $(\mathrm{IN})$, retain $(\mathrm{RT})$, prevent $(\mathrm{PR})$, reduce $(\mathrm{RE})$, mitigate $(\mathrm{MI})$, cooperate $(\mathrm{CP})$, avoid $(\mathrm{AV})$, share $(\mathrm{SH})$, transfer $(\mathrm{TR})$ and control $(\mathrm{CO})$. These data are presented in Table 8. 
Table 8. Summary of the sustainability risk.

\begin{tabular}{|c|c|c|c|c|}
\hline Item & Risk factors & Level & Zones & Risk Response and Practices \\
\hline $\mathrm{R} 1$ & Financial & L1 & $\mathrm{Z4}$ & TR-Engage financial institutions to support liquidity \\
\hline $\mathrm{R} 2$ & Labor Force & L4 & $\mathrm{Z3}$ & $\begin{array}{c}\mathrm{CP} \text {-Engage with suppliers, industry bodies, NGOs to } \\
\text { monitor wages }\end{array}$ \\
\hline $\mathrm{R} 3$ & $\begin{array}{l}\text { Technology and } \\
\text { Innovation }\end{array}$ & L6 & $\mathrm{Z1}$ & $\begin{array}{l}\text { PR-Apply management practices in integrated systems } \\
\text { RT_Accept risk if penalties are low }\end{array}$ \\
\hline $\mathrm{R} 4$ & Boycotts & L2 & $\mathrm{Z4}$ & $\begin{array}{l}\text { RE-Collaborate with tax collection authorities } \\
\text { RT-Accept risk if penalties are low }\end{array}$ \\
\hline R5 & Transportation & L5 & Z1 & IN-Insure against accidents \\
\hline R6 & Natural Hazard & L4 & $\mathrm{Z3}$ & $\begin{array}{l}\text { MI-Contingency plan for SC resilience } \\
\text { IN-Insure against disaster }\end{array}$ \\
\hline R7 & Legal and Responsibility & L6 & $\mathrm{Z1}$ & $\begin{array}{l}\text { PR-Collect and disseminate regulatory information to } \\
\text { ensure compliance } \\
\text { SH-Conduct sustainability audit with key suppliers }\end{array}$ \\
\hline $\mathrm{R} 8$ & Third-Party Service & L4 & $\mathrm{Z3}$ & $\begin{array}{l}\text { SH-Conduct sustainability audit with key suppliers } \\
\text { RT-Accept risk if penalties are low }\end{array}$ \\
\hline R9 & Ecological Damage & L3 & $\mathrm{Z} 4$ & $\begin{array}{l}\text { AV_- Locate facility away from urban areas } \\
\text { IN-Insure against accidents } \\
\text { RT-Accept risk if penalties are low }\end{array}$ \\
\hline R10 & Security & $\mathrm{L} 4$ & $\mathrm{Z3}$ & $\begin{array}{l}\text { RE-Contingency plans for remote work to ensure resilience } \\
\text { in operation } \\
\text { IN_Ensure staff against pandemic }\end{array}$ \\
\hline
\end{tabular}

Response-MI: mitigate; PR: prevent; RE: reduce; IN: insure; CO: control; AV: avoid; CP: cooperate; SH: share; TR: transfer; RT: retain. (R1: Financial. R2: Labor force. R3: Technology and innovation. R4: Boycott. R5: Transportation. R6: Natural hazard. R7: Legal and responsibility. R8: Third-party service. R9: Ecological damage. R10: Security).

Regarding risk responses, the most frequent is the adoption of insurance (accidents insure, disaster insure), which shows that it is still an underdeveloped market in relation to sustainability, as there is too much concern with business profitability loss, and not enough consideration of stakeholders' needs or society's expectations in general. Almost a quarter of the answers given by the experts are that insurance is the best way to manage the identified risk factors.

Another finding of the research on Brazilian companies is that companies have a high propensity to retain (RT) or take risks, such as "accepting risk if penalties are low" being chosen in three different risk cases, corresponding to $18 \%$ of all strategies outlined. The most common responses in companies surveyed by [13] appeared below responses based on insurance or retention in the Brazilian case.

When comparing the results of Brazilian companies with the results presented by [13], it appears that the sample studied by these authors has a high concentration of risk prevention strategies, which corresponds to $24 \%$ of the total strategies identified in this group of items. Then there is the mitigation strategy, with $20 \%$ of the total, and reduction, with $16 \%$ of the total. This leads us to believe that the sample from the previous study showed a high commitment to resolving sustainability risks. As in the study by [13], in the case of Brazilian cosmetic companies, internal environmental risks are perceived as more important. The interconnection between the various risks related to sustainability is high, and this makes it increasingly necessary to explore integrated approaches when studying them.

It is also worth mentioning the absence of alternatives related to control (CO) in Brazil's cosmetic companies; none of the responses to risks are related to this alternative. The cooperate $(\mathrm{CP})$, avoid $(\mathrm{AV})$, share $(\mathrm{SH})$ and transfer (TR) strategies are all still uncommon, having been mentioned by only one of the experts. 


\section{Discussion}

Financial risks occupy the highest level in the ISM-based model. These risks can be derived from the three dimensions of sustainability, linked to a lack of financial resources, involving in large part the nominal value of assets lost through inappropriate actions by the company itself or partners in the supply chain [89]. Financial risks appear at the lowest level of the model due to their limited capacity to influence the system. "Boycott risks" were assessed as level two risks when partitioning the accessibility matrix, right below "financial risks". This suggests that they affect financial risk, but are not affected by it. This is an external aspect of the chain, which may be of economic, social and environmental dimensions, often presenting itself as a form of protest for actions or practices inimical to sustainability $[10,11,86]$. The research identified ecological damage at level three, which is usually manifested by operations interruptions, caused by ecological issues or linked to the impacts on ecosystems [43].

Examples showed how companies that comply with "legal and responsibility risks" are less susceptible to "security risks", "boycott risks" and ultimately "financial risks".

Two risks were identified at the highest level in the ISM-based model, "technology and innovation risks"-linked to the definition of capacity and technological obsolescence $[6,79,83]$, and "legal and responsibility risks" - which may come from the complexity of legislation in some countries, or use without copyright authorization [52]. These are recognized as the two main risks factors, as they influence all others. The ISM-based analysis in this study categorized the risks into six groups according to their degree of interdependence. Level VI risks have the most significant driving force and influence the rest, while other risks are less influential on them.

This research also allows us, with MICMAC analysis, to identify the strength of the relationships between sustainability risks in supply chains. Risks can be separated according to homogeneity and independence factors, such as risks of "technology and innovation", "transportation risks", and "legal and responsibility risks", which are understood as risk factors capable of affecting the entire system, serving as a point of prioritization in action plans. Linkage factors are variables that are affected by changes in the system, but that also affect the system; they are usually positioned in the middle of the model, linking the upper and lower levels of the hierarchical structure: "labor force risks", "natural hazard risks", "third-party service risks" and "security risks". A change in these variables may lead to instability of the system, which is not evident without complete knowledge of the system. "Financial risks", "boycott risks", and "ecological damage risks" are highly dependent factors, absorbing changes in the system more quickly, without the same conductivity capacity, thus serving as indicators of system stability. For example, companies should initially invest in containing these two risks, and thus all other risks in the system will be influenced and should have their impacts minimized.

The identified risks were explored via a method that allows managers to assign priorities in the use of their resources to minimize or mitigate sustainability risks. Resource prioritization improves management and sustainability performance in the organization.

The empirical findings identify the interrelationships between risks factors. The findings of the empirical study have implications for the development of integrated sustainable supply chain strategies. Empirical research shows that most of the systematic risks related to sustainability emanate from the activities or assets of the company or its supply chain. Contrary to the results found in [13], the specialists in the research on the Brazilian sample suggested that although it is desirable to internalize these expenses in the company structure, most of the time, this does not happen.

Sustainability-related risks may be relatively easy to identify, but assessing their impact on business performance is more complex. It is not easy to assign a monetary value to human capital, long-term effects on the environment, and corporate reputation [2]. The operations director of one of the companies approached argued that:

"Sustainability is a necessary evil. The company's priority is to expand, as much as possible, our market share. We adopt transparency in our relations along the supply 
chain to identify and eliminate potentially harmful internal practices or suppliers for the environment and society. However, there are blind spots in our chain, which are suppliers' layers beyond our control. The increase in expenses with auditing processes and companies' certifications in our chain would lead to an increase in costs that perhaps compromise our profitability and for which management is not willing to incur."

Regarding internal issues, which are usually controllable, their impacts may be minimized by companies' actions. On the other hand, external issues have a nature and origin, often systemic, that is hardly controllable. Insurance strategies, which protect the company much more than other stakeholders, have been indicated four times in this survey as the adopted strategy. They were cited as responses to risks related to transportation (insure against accidents), natural hazards (insure against disasters), security (insure staff against pandemic), and ecological damage (insure against accidents). Prevention, mitigation and reduction strategies were only mentioned twice by the experts. In the study by [13], considering only the 10 risks adopted in this empirical approach, prevention strategies are cited six times, mitigate (MI) strategies are cited five times, and reduction strategies four times. The strategies found in [13] to solve problems are much broader.

The Procurement Manager of one of the companies surveyed, with annual sales in the order of USD 50 million, indicated: “... it is necessary to be aware of the risks to the business, many things can happen and in this sense harm the results of the company and the business. Although there are contingency plans for our main mapped risks, there is a need to balance the short-term results with the long-term sustainability of the business, we have an audit program in the main suppliers, but we increasingly identify how we are subject to systematic and external effects, which can put us in check at all times, as in the case of COVID-19, our chain was taken by surprise and after solving this problem, we saw the drop in sales volume. Hence, the sustainability of the business entered a negative spiral or vicious circle, and so far, we are looking to reinvent ourselves."

Ref. [13] indicated that the proposed sustainability risk management framework can be applied at different levels of the supply chain in companies interested in incorporating sustainability risks into their operations strategies. However, it appears that the Brazilian companies' surveyed still lack more structured practices and supplier management systems to deal with sustainability. This indicates the need to develop frameworks that consider external risks to the company, as natural and social impacts are increasingly considered in business activities, which increases the need to offer alternatives so that companies do not enter into the vicious circle of prejudice and a lack of perspective. Companies tend to think of sustainability as an additional cost or a "necessary evil", often referring to the idea of a fad. Therefore, these companies lack a broader vision of the world, with a perspective of gains to be derived from sustainability, whether for brand appreciation or employees' sense of pride. The companies mainly adopt strategies to preserve business profitability, and in many cases, they assume insurance or even risk-taking is the best path.

Brazilian companies perceive sustainability only as a cost to be avoided, as they have a reductionist view, focusing on the short term. Contrary to this view, Ref. [106] indicates that sustainability should be seen as a path to cost-saving advantages. However, companies can make the best of sustainability [4]. This distinction between theory and practice indicates that there is still a level of maturity to be attained in emerging markets such as Brazil. The cost leadership advantages that companies can obtain by incorporating sustainability into the management of their suppliers, as indicated by [2], stem from a complete approach to processes management, wherein risks are generated that are still underappreciated in Brazilian companies.

In addition to the long-term cost advantages that Brazilian companies fail to perceive, the value creation that a company can experience by operating with sustainability is also mentioned in the literature as a benefit. Companies with this differentiating ability can become leaders in their areas. They can gain leadership advantages via differentiation, and this type of leadership has an essential advantage over cost leadership, as differentiated companies are more difficult to copy. Thinking about sustainability benefits involves anticipating the identification and management of sustainability risks in supply chains, 
as [2] indicates, which will allows better resource allocation in these chains. In this sense, managing sustainability risks in supply chains will create opportunities to save costs and make supply chains more sustainable. Companies that lead this movement in different markets will be leaders in sustainability, and in turn, will become differentiated companies. Thus, it is necessary to change the mental model, and companies need to think about ways to enable sustainability in their supply chains.

The Brazilian companies analyzed in this study do not yet focus on responses to typical supply chain risks; the strategies adopted aim to reduce the complexity and lead times, minimize costs, improve responsiveness, and optimize operational efficiency [4,30]. Efforts to address sustainability-related risks, on the other hand, are aimed at eliminating the negative consequences for a company's brand, image or shareholder value [4]. To achieve successful sustainability operationalization in supply chains [2,107], an operational notion of supply chain sustainability is necessary. The theoretical foundations for implementing effective, sustainable operations and supply chain strategies are still yet to be developed.

It can be seen from the studied companies' behavior that there is little capacity to incorporate SDGs, since these companies exhibit behavior that is strongly focused on the continuity of their operations, not on the long-term business strategy that the SDGs can support. Therefore, companies lose an opportunity to influence their customer and supplier chain positively, and it is unlikely that their behavior will allow for the dissemination of good sustainability practices, focused on sustainable industrialization and the promotion of innovation, as in the SDGs [1]. There is no reinforcement of the guarantee of sustainable consumption and production patterns, or of the minimization of destructive impacts on the planet, as in the case of SDG 12 [1].

\section{Conclusions}

This research investigated potential sustainability risk factors in supply chains using the ISM and MICMAC tools to understand the hierarchy and interrelationships between risk factors. The approach used in this research enables the development of a hierarchical model for sustainability risks, offering a structured alternative means to interpret the existing links between variables. This research positioned "technology and innovation risks" and "legal and responsibility risks" as variables with more significant influence. As such, these risk factors have a greater influence on the system, and more effective actions to minimize risks should be initiated. For example, companies should initially invest in containing these two risks, and thus all other risks in the system would be influenced. The hierarchical model shows that that companies that comply with "legal and responsibility risks" are less susceptible to "security risks" than "boycott risks", and ultimately "financial risks".

This research also reveals that "financial risks", "boycott risks", and "ecological damage risks" are perceived as the factors that least influence sustainability risks, since, in addition to being assigned to lower partitioning level, they are in the zone of dependent factors in the MICMAC analysis, which are influenced by the entire system, although without the same ability to influence others. MICMAC analysis reinforces the importance of the variables "technology and innovation risks", "legal and responsibility risks" and "transportation risks" as the elements with the most significant influence over the entire system, making them the main focus of companies' actions.

The methodology used was innovative in identifying sustainability risks and their interrelationships for the Brazilian cosmetic segment, representing an adaptation of a tool already successfully used in other research fields. The risks identified were explored via a method that will allow managers to develop priorities in their use of resources to minimize or mitigate sustainability risks, and consequently to improve their management and sustainability performance in the organization.

This study contributes to the literature by considering which sustainable supply chain strategies the Brazilian cosmetic industry could adopt, identifying pertinent sustainabilityrelated risks and analyzing their possible effects. These Brazilian cosmetic companies 
tend to think of sustainability as an additional cost or a "necessary evil", often alluding to the idea of a fad. Therefore, these companies lack a broader vision of the world, with a perspective of the gains to be derived from sustainability, in terms of both brand appreciation and employees' sense of pride. These companies usually adopt strategies to preserve the business' profitability, and in many cases, they pursue insurance or risk-taking as the best path.

The results show that Brazilian cosmetic companies often fail to take advantage of an opportunity to obtain a leadership position in cost savings, differentiation, and even engagement with their partners, which can positively influence the SDGs.

Some limitations were found in this research, which should be considered: (a) the results reported are related to the consulted specialists; (b) the results are only applicable to Brazilian cosmetic companies, and cannot be generalized to other companies.

As a suggestion for future research that expands on this study, the examination of other stakeholders in the cosmetic supply chain is also suggested, such as associations, unions and others. Applying the methodology developed in this research in other economic sectors is also suggested, permitting the confirmation or rejection of the hierarchies found, and helping to seek ways to capture the imprecision associated with human judgment.

Author Contributions: Conceptualization, A.L.R. and L.M.D.F.F.; methodology, A.L.R.; software, A.L.R.; validation, A.L.R., L.M.D.F.F. and S.S.F.S.C.; formal analysis, A.L.R.; investigation, A.L.R.; resources, A.L.R.; data curation, A.L.R.; writing—original draft preparation, A.L.R.; writing-review and editing, L.M.D.F.F. and S.S.F.S.C.; supervision, L.M.D.F.F. and S.S.F.S.C. All authors have read and agreed to the published version of the manuscript.

Funding: This research was funded by FCT-FUNDAÇÃO PARA A CIÊNCIA E TECNOLOGIA, grant number UIDB/00285/2020.

Institutional Review Board Statement: Not applicable.

Informed Consent Statement: Informed consent was obtained from all subjects involved in the study.

Data Availability Statement: Not applicable.

Conflicts of Interest: The authors declare no conflict of interest.

\section{References}

1. United Nations. Take Action for the Sustainable Development Goals. Common indicators. Available online: https://www.un.org/ sustainabledevelopment/sustainable-development-goals/ (accessed on 2 September 2020).

2. Hofmann, H.; Busse, C.; Bode, C.; Henke, M. Sustainability-Related Supply Chain Risks: Conceptualization \& Management. Bus. Strategy Environ. 2014, 23, 160-172.

3. Busse, C.; Kach, A.; Bode, C. Sustainability \& the False Sense of Legitimacy: How Institutional Distance Augments Risk in Global Supply Chains. J. Bus. Logist. 2016, 37, 312-328.

4. Reinerth, D.; Busse, C.; Wagner, S.M. Using country sustainability risk to inform sustainable supply chain management: A design science study. J. Bus. Logist. 2019, 40, 241-264. [CrossRef]

5. Bregman, R.; Peng, D.X.; Chin, W. The effect of controversial global sourcing practices on the ethical judgments and intentions of US consumers. J. Oper. Manag. 2015, 36, 229-243. [CrossRef]

6. Bui, T.D.; Tsai, F.M.; Tseng, M.L.; Tan, R.R.; Yu, K.D.; Lim, M.K. Sustainable supply chain management towards disruption and organizational ambidexterity: A data driven bibliometric analysis. Sustain. Prod. Consum. 2021, 26, 373-410. [CrossRef]

7. Ehrgott, M.; Reimann, F.; Kaufmann, L.; Carter, C. Environmental development of emerging economy suppliers: Antecedents \& outcomes. J. Bus. Logist. 2013, 34, 131-147.

8. Busse, C. Doing Well by Doing Good? The Self-interest of Buying Firms \& Sustainable Supply Chain Management. J. Supply Chain. Manag. 2016, 52, $28-47$.

9. Syed, M.W.; Li, J.Z.; Junaid, M.; Ye, X.; Ziaullah, M. An Empirical Examination of Sustainable Supply Chain Risk and Integration Practices: A Performance-Based Evidence from Pakistan. Sustainability 2019, 11, 5334. [CrossRef]

10. Kim, S.; Wagner, S.M.; Colicchia, C. The impact of supplier sustainability risk on shareholder value. J. Supply Chain. Manag. 2019, 55, 71-87. [CrossRef]

11. Kim, S.; Wagner, S.M. Examining the stock price effect of corruption risk in the supply chain. Decis. Sci. 2021, 52, 833-865. [CrossRef]

12. Tseng, M.L.; Tran, T.P.T.; Ha, M.H.; Bui, T.D.; Lim, M.L. Sustainable industrial and operation engineering trends and challenges Toward Industry 4.0: A data driven analysis. J. Ind. Prod. Eng. 2021, 38, 1-18. [CrossRef] 
13. Giannakis, M.; Papadopoulos, T. Supply chain sustainability: A risk management approach. Int. J. Prod. Econ. 2016, 171, 455-470. [CrossRef]

14. Awasthi, A.; Govindan, K.; Gold, S. Multi-tier sustainable global supplier selection using a fuzzy AHP-VIKOR based approach. Int. J. Prod. Econ. 2018, 195, 106-117. [CrossRef]

15. Ahmadi, H.; Petrudi, S.; Wang, X. Integrating sustainability into supplier selection with analytical hierarchy process \& improved grey relational analysis: A case of telecom industry. Int. J. Adv. Manuf. Technol. 2017, 90, 2413-2427.

16. Bartley, T.; Child, C. Movements, markets and fields: The effects of anti-sweatshop campaigns on U.S. firms, 1993-2000. Soc. Forces 2011, 90, 425-451. [CrossRef]

17. Jiang, B. The effects of interorganizational governance on supplier's compliance with SCC: An empirical examination of compliant and non-compliant suppliers. J. Oper. Manag. 2009, 27, 267-280. [CrossRef]

18. Pullman, M.E.; Maloni, M.J.; Carter, C.R. Alimentos para o pensamento: Práticas de sustentabilidade socioambiental e resultados de desempenho. J. Supply Chain Manag. 2009, 45, 38-54. [CrossRef]

19. Foerstl, K.; Reuter, C.; Hartmann, E.; Blome, C. Managing supplier sustainability risks in a dynamically changing environmentsustainable supplier management in the chemical industry. J. Purch. Supply Manag. 2010, 16, 118-130. [CrossRef]

20. Xu, M.; Cui, Y.; Hu, M.; Xu, X.; Zhang, Z.; Liang, S.; Qu, S. Supply chain sustainability risk \& assessment. J. Clean. Prod. 2019, 225, 857-867.

21. Elkington, J. Enter the Triple Bottom Line. In The Triple Bottom Line: Does It All Add Up? Henriques, A., Richardson, J., Eds.; Earthscan: London, UK, 2004; pp. 1-16.

22. Schleper, M.; Busse, C. Toward a standardized supplier code of ethics: Development of a design concept based on diffusion of innovation theory. Logist. Res. 2013, 6, 187-216. [CrossRef]

23. Bom, S.; Jorge, J.; Ribeiro, H.M.; Marto, J. A Step Forward on Sustainability in the Cosmetics Industry: A review. J. Clean. Prod. 2019, 225, 270-290. [CrossRef]

24. Bom, S.; Ribeiro, H.M.; Marto, J. Sustainability Calculator: A Tool to Assess Sustainability in Cosmetic Products. Sustainability 2020, 12, 1437. [CrossRef]

25. Lee, Y.-H.; Chen, S.-L. Effect of Green Attributes Transparency on WTA for Green Cosmetics: Mediating Effects of CSR and Green Brand Concepts. Sustainability 2019, 11, 5258. [CrossRef]

26. Euromonitor Beauty \& Personal Care in Brazil. 2019. Available online: https://www.euromonitor.com/beauty-and-personalcare-in-brazil/report (accessed on 12 December 2019).

27. Pitman, S. Brazilian Cosmetic Manufacturing Booms. Available online: https://www.cosmeticsdesign-europe.com/Article/2006 /02/10/Brazilian-cosmetic-manufacturing-booms (accessed on 26 July 2021).

28. Dube, A.; Gawande, R. Analysis of green supply chain barriers using integrated ISM-fuzzy MICMAC approach. Benchmarking Int. J. 2016, 23, 1558-1578. [CrossRef]

29. Romano, A.L.; Teixeira, I.T.; Alves Filho, A.G.; Helleno, A.L. Avaliação da sustentabilidade corporativa e da cultura organizacionalsurvey no setor brasileiro de cosméticos. Rev. De Adm. Da UFSM 2018, 11, 1305-1323. [CrossRef]

30. Attri, R.; Grover, S. Modelling the quality enabled factors in initiation stage of production system life cycle. Benchmarking Int. J. 2017, 24, 163-183. [CrossRef]

31. Kwak, D.; Rodrigues, V.; Mason, R.; Pettit, S.; Beresford, A. Risk interaction identification in international supply chain logistics: Developing a holistic model. Int. J. Oper. Prod. Manag. 2018, 38, 372-389. [CrossRef]

32. Magalhães, V.S.; Ferreira, L.M.; Silva, C. Using a Methodological Approach to Model Causes of Food Loss and Waste in Fruit and Vegetable Supply Chains. J. Clean. Prod. 2021, 283, 124574. [CrossRef]

33. Troche-Escobar, J.; Lepikson, H.; Mendonça Freires, F. A Study of Supply Chain Risk in the Brazilian Wind Power Projects by Interpretive Structural Modeling and MICMAC Analysis. Sustainability 2018, 10, 3442. [CrossRef]

34. Kumar, A.; Mangla, S.; Kumar, P.; Karamperidis, S. Challenges in perishable food supply chains for sustainability management: A developing economy perspective. Bus. Strat. Environ. 2020, 29, 1809-1831. [CrossRef]

35. Magalhães, V.S.; Ferreira, L.M.; César, A.S.; Bonfim, R.M.; Silva, C. Food loss and waste in the Brazilian beef supply chain: An empirical analysis. Int. J. Logist. Manag. 2021, 32, 214-236. [CrossRef]

36. Romano, A.L.; Teixeira, I.T.; Alves Filho, A.G.; Helleno, A.L. A study on organizational culture in the brazilian cosmetics sector. Rev. Pensam. Contemp. Em Adm. 2014, 9, 142-158.

37. Freeman, R.E. Strategic Management: A Stakeholder Approach; Pitman: Boston, MA, USA, 1984.

38. Freeman, R.E.; Moutchnik, A. Stakeholder management and Corporate Social Responsibility: Questions and answers. Umwelt. Wirtsch. Forum. 2013, 21, 5-9. [CrossRef]

39. Okuyama, Y.; Santos, J. Disaster impact and input-output analysis. Econ. Syst. Res. 2014, 26, 1-12. [CrossRef]

40. Altay, N.; Ramirez, A. Impact of disasters on firms in different sectors: Implications for supply chains. Supply Chain Manag. 2010, 46, 59-80. [CrossRef]

41. Fiksel, J. Evaluating supply chain sustainability. Chem. Eng. Prog. 2010, 106, 28-38.

42. Lozano, R.; Huisingh, D. Inter-linking issues and dimensions in sustainability reporting. J. Clean. Prod. 2011, 19, 99-107. [CrossRef] 
43. Acquaye, A.; Feng, K.; Oppon, E.; Salhi, S.; Ibn-Mohammed, T.; Genovese, A.; Hubacek, K. Measuring the environmental sustainability performance of global supply chains: A multi-regional input-output analysis for carbon, sulphur oxide \& water footprints. J. Environ. Manag. 2017, 187, 571-585.

44. Dubey, R.; Gunasekaran, A.; Childe, S.J.; Papadopoulos, T.; Hazen, B.; Giannakis, M.; Roubaud, D. Examining the effect of external pressures and organizational culture on shaping performance measurement systems for sustainability benchmarking. Int. J. Prod. Econ. 2017, 193, 63-76. [CrossRef]

45. Chan, F. Performance measurement in a supply chain. Int. J. Adv. Manuf. Technol. 2003, 21, 534-548. [CrossRef]

46. Cunha, L.; Ceryno, P.; Leiras, A. Social Supply Chain Risk Management: A taxonomy, a framework \& a research agenda. J. Clean. Prod. 2019, 20, 1101-1110.

47. Kabat, M.; Desalvo, A.; Egan, J. The tip of the iceberg: Media coverage of 'slave labor' in Argentina. Lat. Am. Perspect. 2017, 44, 50-62. [CrossRef]

48. Blackburn, W.R. The Sustainability Handbook: The Complete Management Guide to Achieving Social, Economic E Environmental Responsibility; Earth-Scan: London, UK, 2007.

49. Torres-Ruiz, A.; Ravindran, A.R. Multiple criteria framework for the sustainability risk assessment of a supplier portfolio. J. Clean. Prod. 2018, 172, 4478-4493. [CrossRef]

50. Carter, C.; Jennings, M. The role of purchasing in corporate social responsibility: A structural equation analysis. J. Bus. Logist. 2004, 25, 145-186. [CrossRef]

51. Govindan, K.; Azevedo, S.G.; Carvalho, H.; Machado, V. Impact of supply chain management practices on Sustainability. J. Clean. Prod. 2014, 85, 212-225. [CrossRef]

52. Grimm, J.H.; Hofstetter, J.S.; Sarkis, J. Exploring sub-suppliers' compliance with corporate sustainability standards. J. Clean. Prod. 2016, 112, 1971-1984. [CrossRef]

53. Mulhall, R.; Bryson, J. Energy price risk \& the sustainability of demand side supply chains. Appl. Energy 2014, 123, 327-334.

54. Mulyati, H.; Geldermann, J. Managing risks in the Indonesian seaweed supply chain. Clean Technol. Environ. Policy 2017, 19, 175-189. [CrossRef]

55. Sodhi, M.; Son, B.; Tang, C. Researchers' perspectives on supply chain risk management. Prod. Oper. Manag. 2012, 21, 1-13. [CrossRef]

56. Zakeri, A.; Dehghanian, F.; Fahimnia, B.; Sarkis, J. Carbon pricing versus emissions trading: A supply chain planning perspective. Int. J. Prod. Econ. 2015, 164, 197-205. [CrossRef]

57. Pongrácz, E. The environmental impacts of packaging. In Environmentally Conscious Materials E Chemicals Processing; Kutz, M., Ed.; John Wiley \& Sons, Inc.: Hoboken, NJ, USA, 2007; pp. 237-278.

58. Hsieh, C. Disaster risk assessment of ports based on the perspective of vulnerability. Nat. Hazards 2014, 74, 851-864. [CrossRef]

59. International Monetary Fund_IMF Small States' Resilience to Natural Disasters \& Climate Change: Role for the IMF, IMF Policy Paper; International Monetary Fund: Washington, DC, USA, 2016.

60. Smith, J.; Schellnhuber, H.; Mirza, M. Vulnerability to Climate Change \& Reasons for Concern: A Synthesis. In Climate Change 2001: Impacts, Adaptation E Vulnerability. Contribution of Working Group II to the Third Assessment Report of the Intergovernmental Panel on Climate Change; McCarthy, J., Canziani, O.F., Leary, N.A., Dokken, D.J., White, K.S., Eds.; Cambridge University Press: Cambridge, UK, 2001; pp. 914-967.

61. Halldórsson, Á.; Kotzab, H.; Skjott-Larsen, T. Supply chain management on the crossroad to sustainability: A blessing or a curse? Logist Res. 2009, 1, 83-94. [CrossRef]

62. Cosgrove, W.; Loucks, D. Water management: Current \& future challenges \& research directions. Water Resour. Res. 2015, 51, 4823-4839.

63. Huq, F.; Stevenson, M.; Zorzini, M. Social sustainability in developing country suppliers: An exploratory study in the ready-made garments industry of Bangladesh. Intern. J. Oper. Prod. Manag. 2014, 34, 610-638.

64. Pagell, M.; Wu, Z.; Wasserman, M.E. Thinking differently about purchasing portfolios: An assessment of sustainable sourcing. J. Supply Chain. Manag. 2010, 46, 57-73. [CrossRef]

65. Godar, J.; Suavet, C.; Gardner, T.; Dawkins, E.; Meyfroidt, P. Balancing detail \& scale in assessing transparency to improve the governance of agricultural commodity supply chains. Environ. Res. Lett. 2016, 11, 035015. [CrossRef]

66. Valinejad, F.; Rahmani, D. Sustainability risk management in the supply chain of telecommunication companies: A case study. J. Clean. Prod. 2018, 203, 53-67. [CrossRef]

67. Clift, R. Metrics for supply chain sustainability. Clean Technol. Environ. Policy 2003, 5, 240-247. [CrossRef]

68. Simas, M.; Pacca, S. Assessing employment in renewable energy technologies: A case study for wind power in Brazil. Renew. Sustain. Energy Rev. 2014, 31, 83-90. [CrossRef]

69. Diaz, K.; O'Hanlon, N. IssueWeb: A Guide \& Sourcebook for Researching Controversial Issues on the Web; Libraries Unlimited: Westport, CT, USA, 2004.

70. People for the Ethical Treatment of Animals_PETA. 2014. Available online: www.peta.org (accessed on 10 December 2020).

71. Hartman, L.; DesJardins, J.; MacDonald, C. Business Ethics: Decision Making for Personal Integrity E Social Responsibility, 4th ed.; Mcgraw-Hill: New York, NY, USA, 2018.

72. Carter, C.; Rogers, D. A framework of sustainable supply chain management: Moving toward new theory. Int. J. Phys. Distrib. Logist. Manag. 2008, 38, 360-387. [CrossRef] 
73. Madhav, N.; Oppenheim, B.; Gallivan, M.; Mulembakani, P.; Rubin, E.; Wolfe, E. Chapter 17—Pandemics: Risks, Impacts, \& Mitigation. In The International Bank for Reconstruction \& Development; Jamison, D., Gelband, H., Horton, S., Jha, P., Laxminarayan, R., Mock, C., Nugent., R., Eds.; The World Bank: Washington, DC, USA, 2017.

74. International Labour Organisation-ILO. 2014. Available online: http://www.ilo.org/ipec/facts/lang--en/index.htm (accessed on 20 December 2020).

75. Smith-Bingham, R. The Emerging Risks Quandary. Anticipating Threats Hidden in Plain Sight; Marsh \& McLennan: New York, NY, USA, 2016.

76. Connor, J. The competition Law Review, Anti-Cartel Enforcement by the DOJ: An Appraisal. Compet. Law Rev. 2008, 5, 89-121.

77. Sójka, J.; Wempe, J. (Eds.) Business Challenging Business Ethics: New Instruments for Coping with Diversity in International Business: The 12th Annual EBEN Conference; Springer: Dordrecht, The Netherlands, 2000; pp. 193-203.

78. Humphreys, K. What Every Engineer Should Know about Ethics; Marcel Dekker, Inc.: New York, NY, USA, 1999.

79. Prostean, G.; Badea, A.; Vasar, C.; Octavian, P. Risk variables in wind power supply chain. Procedia Soc. Behav. Sci. 2014, 124, 124-132. [CrossRef]

80. AbdelWarith, K.; Anastasopoulos, P.; Richardson, W. Design of local roadway infrastructure to service sustainable energy facilities. Energy Sustain. Soc. 2014, 4, 14. [CrossRef]

81. González, R.; Gascó, J.; Llopis, J. Information Systems Outsourcing Reasons \& Risks: Review \& Evolution. J. Glob. Inf. Technol. Manag. 2016, 19, 223-249. [CrossRef]

82. Yusuf, Y.; Menhat, M.; Abubakar, T.; Ogbuke, N. Agile capabilities as necessary conditions for maximising sustainable supply chain performance: An em-pirical investigation. Int. J. Prod. Econ. 2019, 222, 107501.

83. Madavar, M.; Nezhad, M.; Aslani, A.; Naaranoja, M. Analysis of Generations of Wind Power Technologies Based on Technology Life Cycle Approach. Distrib. Gener. Altern. Energy J. 2017, 32, 52-79. [CrossRef]

84. Hajmohammad, S.; Vachon, S. Mitigation, Avoidance, or Acceptance? Managing Supplier Sustainability Risk. J. Supply Chain. Manag. 2016, 52, 48-65. [CrossRef]

85. Dixon, M.; Martin, A.W.; Nau, M. Social Protest \& Corporate Change: Brand Visibility, Third-Party Influence, \& the Responsiveness of Corporations to Activist Campaigns. Mobilization Int. Q. 2016, 21, 65-82.

86. Zimmer, K.; Fröhling, M.; Schultmann, F. Sustainable supplier management-A review of models supporting sustainable supplier selection, monitoring \& development. Int. J. Prod. Res. 2016, 54, 1412-1442.

87. Bacon, R.; Kojima, M. Coping with Oil Price Volatility. Energy Sector Management Assistance Program (ESMAP) Energy Security Special Report; No. 005/08; World Bank: Washington, DC, USA, 2008.

88. Li, W.; Choi, T.-M.; Chow, P.-S. Risk \& benefits brought by formal sustainability programs on fashin enterprises under market disruption. Resour. Conserv. Recycl. 2015, 104, 348-353.

89. Wewege, L.; Thomsett, M. The Digital Banking Revolution-How Fintech Companies are Transforming the Retail. Banking Industry Through Disruptive Financial Innovation, 3rd ed.; Walter de Gruyter Inc.: Boston, MA, USA; Berlin, Germany, 2019. [CrossRef]

90. Ganguly, G.; Setzer, J.; Heyvaert, V. If at First You Don't Succeed: Suing Corporations for Climate Change. Oxf. J. Leg. Stud. 2018, 38, 841-868. [CrossRef]

91. Roehrich, J.; Grosvold, J.; Hoejmose, S. Reputational risks and sustainable supply chain management: Decision making under bounded rationality. Int. J. Oper. Prod. Manag. 2014, 34, 695-719. [CrossRef]

92. Bowen, F. Does size matter? Organizational slack and visibility as alternative explanations for environmental responsiveness. Bus. Soc. 2002, 41, 118-124. [CrossRef]

93. Reuter, C.; Foerstl, K.; Hartmann, E.; Blome, C. Sustainable global supplier management: The role of dynamic capabilities in achieving competitive advantage. J. Supply Chain. Manag. 2010, 46, 45-63. [CrossRef]

94. Kleindorfer, P.; Saad, G. Managing disruption risks in supply chains. Prod. Oper. Manag. 2005, 14, 53-68. [CrossRef]

95. Blome, C.; Schoenherr, T. Supply chain risk management in financial crises-A multiple case-study approach. Int. J. Prod. Econ. 2011, 134, 43-57. [CrossRef]

96. Klassen, R.D.; Vereecke, A. Social issues in supply chains: Capabilities link responsibility, risk (opportunity), and performance. Int. J. Prod. Econ. 2012, 140, 103-115. [CrossRef]

97. Yavari, M.; Ajalli, P. Suppliers' coalition strategy for green-Resilient supply chain network design. J. Ind. Prod. Eng. 2021, 38, 197-212. [CrossRef]

98. Ritchie, B.; Brindley, C. Supply chain risk management and performance: A guiding framework for future development. Int. J. Oper. Prod. Manag. 2007, 27, 303-322. [CrossRef]

99. Jüttner, U.; Peck, H.; Christopher, M. Supply chain risk management: Outlining an agenda for future research. Int. J. Logist. Res. Appl. 2003, 6, 197-210. [CrossRef]

100. Miller, K. A framework for integrated risk management in international business. J. Int. Bus. Stud. 1992, 23, 311-331. [CrossRef]

101. Vose, D. Risk Analysis: A Quantitative Guide, 3rd ed.; Wiley: Hoboken, NJ, USA, 2008.

102. Bai, C.; Sarkis, J. Green supplier development: Analytical evaluation using rough set theory. J. Clean. Prod. 2010, 18, 1200-1210. [CrossRef]

103. Zhao, X.; Flynn, B.B.; Roth, A.V. Decision sciences research in China: Current status, opportunities, and propositions for research in supply chain management, logistics, and quality management. Decis. Sci. 2007, 38, 39-80. [CrossRef] 
104. Jiang, X.; Lu, K.; Xia, B.; Liu, Y.; Cui, C. Identifying Significant Risks and Analyzing Risk Relationship for Construction PPP Projects in China Using Integrated FISM-MICMAC Approach. Sustainability 2019, 11, 5206. [CrossRef]

105. Seuring, S.; Muller, M. From a literature review to a conceptual framework for sustainable supply chain management. J. Clean. Prod. 2008, 16, 1699-1710. [CrossRef]

106. Wang, Z.; Sarkis, J. Investigating the relationship of sustainable supply chain management with corporate financial performance. Int. J. Prod. Perform. Manag. 2013, 63, 871-888. [CrossRef]

107. Krysiak, F. Risk management as a tool for sustainability. J. Bus. Ethics 2009, 85, 483-492. [CrossRef]

108. Saunders, M.; Lewis, P.; Thornhill, A. Research Methods for Business Students, 8th ed.; Financial Times Prentice Hall: Harlow, UK, 2019.

109. Greenbaum, T. The Handbook for Focus Group Research; Sage: Thousand Oaks, CA, USA, 1998.

110. Sushil. Interpreting the Interpretive Structural Model. Glob. J. Flex. Syst. Manag. 2012, 13, 87-106. [CrossRef]

111. Singh, M.; Shankar, R.; Narain, R.; Agarwal, A. An interpretive structural modeling of knowledge management in engineering industries. J. Adv. Manag. Res. 2003, 1, 28-40. [CrossRef]

112. Charan, P.; Shankar, R.; Baisya, R. Analysis of interactions among the variables of supply chain performance measurement system implementation. Bus. Process. Manag. J. 2008, 14, 512-529. [CrossRef]

113. Jharkharia, S.; Shankar, R. IT enablement of supply chains: Modeling the enablers. Int. J. Product. Perform. Manag. 2004, 53, 700-712. [CrossRef]

114. Kumar, P.; Shankar, R.; Yadav, S. Flexibility in global supply chain: Modeling the enablers. J. Model. Manag. 2008, 3, $277-297$. [CrossRef]

115. Bravo, A.; Carvalho, J. Challenging times to pharmaceutical supply chains towards sustainability: A case study application. Int. J. Procure. Manag. 2014, 8, 126. [CrossRef]

116. Gao, T.; Erokhin, V.; Arskiy, A. Dynamic Optimization of Fuel and Logistics Costs as a Tool in Pursuing Economic Sustainability of a Farm. Sustainability 2019, 11, 5463. [CrossRef] 